\title{
Biological Investigation of Amaryllidaceae Alkaloid Extracts from the Bulbs of Pancratium trianthum Collected in the Senegalese Flora
}

\author{
Seydou Ka ${ }^{1,2} \mathbb{D}^{\text {, Natacha Mérindol }}{ }^{1} \mathbb{(}$, Insa Seck ${ }^{2} \mathbb{D}$, Simon Ricard ${ }^{1}$, Abdoulaye Diop ${ }^{3}$, \\ Cheikh Saad Bouh Boye ${ }^{3}$, Karima Landelouci ${ }^{4}$, Benoit Daoust ${ }^{1}$, Lionel Berthoux ${ }^{4}{ }^{\oplus}$, Geneviève Pépin ${ }^{4}$, \\ Matar Seck ${ }^{2}$ and Isabel Desgagné-Penix $1,5, * \mathbb{B}$
}

\section{check for} updates

Citation: Ka, S.; Mérindol, N.; Seck, I.; Ricard, S.; Diop, A.; Boye, C.S.B.; Landelouci, K.; Daoust, B.; Berthoux, L.; Pépin, G.; et al. Biological Investigation of Amaryllidaceae Alkaloid Extracts from the Bulbs of Pancratium trianthum Collected in the Senegalese Flora. Molecules 2021, 26, 7382. https://doi.org/10.3390/ molecules 26237382

Academic Editor: Francisco Leon

Received: 3 November 2021

Accepted: 3 December 2021

Published: 5 December 2021

Publisher's Note: MDPI stays neutral with regard to jurisdictional claims in published maps and institutional affiliations.

Copyright: (c) 2021 by the authors. Licensee MDPI, Basel, Switzerland. This article is an open access article distributed under the terms and conditions of the Creative Commons Attribution (CC BY) license (https:/ / creativecommons.org/licenses/by/ $4.0 /)$.
1 Département de Chimie, Biochimie et Physique, Université du Québec à Trois-Rivières, Trois-Rivières, QC G8Z 4M3, Canada; Seydou.Ka@uqtr.ca (S.K.); Natacha.Merindol@uqtr.ca (N.M.); Simon.Ricard@uqtr.ca (S.R.); Benoit.Daoust@uqtr.ca (B.D.)

2 Laboratoire de Chimie Organique et Thérapeutique, Faculté de Médecine, de Pharmacie, et d'Odontologie de Dakar, Dakar B.P. 5005, Senegal; insa1.seck@ucad.edu.sn (I.S.); matarsec@yahoo.fr (M.S.)

3 Laboratoire Bactériologie-Virologie, CHU Aristide Le Dantec, Université Cheikh Anta Diop de Dakar, Dakar B.P. 5005, Senegal; laycoumba@yahoo.fr (A.D.); cheikh.boye@ucad.edu.sn (C.S.B.B.)

4 Département de Biologie Médicale, Université du Québec à Trois-Rivières, Trois-Rivières, QC G8Z 4M3, Canada; Karima.Landelouci@uqtr.ca (K.L.); Lionel.Berthoux@uqtr.ca (L.B.); Genevieve.Pepin3@uqtr.ca (G.P.)

5 Groupe de Recherche en Biologie Végétale, Université du Québec à Trois-Rivières, Trois-Rivières, QC G8Z 4M3, Canada

* Correspondence: Isabel.Desgagne-Penix@uqtr.ca; Tel.: +1-819-376-5011

Abstract: Amaryllidaceae plants are rich in alkaloids with biological properties. Pancratium trianthum is an Amaryllidaceae species widely used in African folk medicine to treat several diseases such as central nervous system disorders, tumors, and microbial infections, and it is used to heal wounds. The current investigation explored the biological properties of alkaloid extracts from bulbs of $P$. trianthum collected in the Senegalese flora. Alkaloid extracts were analyzed and identified by chromatography and mass spectrometry. Alkaloid extracts from $P$. trianthum displayed pleiotropic biological properties. Cytotoxic activity of the extracts was determined on hepatocarcinoma Huh7 cells and on acute monocytic leukemia THP-1 cells, while agar diffusion and microdilution assays were used to evaluate antibacterial activity. Antiviral activity was measured by infection of extract-treated cells with dengue virus $\left(\mathrm{DENV}_{\mathrm{GFP}}\right)$ and human immunodeficiency virus-1 (HIV-1 ${ }_{\mathrm{GFP}}$ ) reporter vectors. Cytotoxicity and viral inhibition were the most striking of $P$. trianthum's extract activities. Importantly, noncytotoxic concentrations were highly effective in completely preventing $\mathrm{DENV}_{\mathrm{GFP}}$ replication and in reducing pseudotyped HIV-1 $1_{\text {GFP }}$ infection levels. Our results show that $P$. trianthum is a rich source of molecules for the potential discovery of new treatments against various diseases. Herein, we provide scientific evidence to rationalize the traditional uses of $P$. trianthum for wound treatment as an anti-dermatosis and antiseptic agent.

Keywords: alkaloid; Amaryllidaceae; Pancratium trianthum; antiviral; antimicrobial; dengue virus; HIV

\section{Introduction}

The Amaryllidaceae family encompasses over 1600 species scattered all around the globe and is among the top 20 most considered medicinal plant families [1]. They are bulbous flowering plants also exploited for ornamental purposes. Approximately one-third of known Amaryllidaceae species grow in South Africa, and they are commonly used in folk medicine [2,3]. Traditional usage of Amaryllidaceae ranges from simple health problems (e.g., headache, cough, boils) to complicated diseases (e.g., cancer, tuberculosis, diabetes). Amaryllidaceae preparations are recognized for their antimicrobial, anti-tumoral, antiacetylcholinesterase (AChE), and cytotoxic properties [4-16]. West African Amaryllidaceae 
species such as Pancratium sp., collected in Senegal for traditional medicine [17], have been scarcely studied [18]. The genus Pancratium contains approximately 20 species, extending from the Canary Islands through the Mediterranean region to tropical Asia, and from West Africa to Namibia [19]. P. trianthum Herb. (English name: pancratium lily; local names: baka, ngada, tondut) [20] plant extracts are traditionally used for irritation-calming, wound-healing, anti-oedema, anti-dermatosis, anti-septic, anti-epileptic, psychotropic, and fungicidal properties $[17,21]$. P. trianthum is considered to be toxic in Senegal and Sudan and thus is restricted to external usage only [5], while it is considered edible in Nigeria and Western Sahara [4,22].

Phytochemical studies have shown that the biological properties of Amaryllidaceae largely originate from a specific class of specialized metabolites that they produce, called the Amaryllidaceae alkaloids (AAs) [23-25]. AA classification describes nine different AA-types according to their structure and their biosynthesis pathway [24]. Galanthamine, a widely occurring AA, is currently used as an AChE inhibitor to treat Alzheimer's disease symptoms [26]. Several other pharmaceutically relevant AAs are under study, such as crinamine for the treatment of Parkinson's disease [27] or cherylline for its antiviral properties $[28,29]$. Lycorine, crinine, and haemanthamine were previously described as the most abundant types of alkaloids in the Pancratium genus [30]. A study published in 1983 identified the AAs trisphaeridine, hippeastrine, hordenine, pancratine, tazettine, lycorine, galanthamine, and trianthine from aerial and underground plant parts of P. trianthum collected from the Botanical Garden of Pyatigorsk State Pharmaceutical Academy in Russia [31,32]. However, no study has reported on the AA content nor the biological activities of $P$. trianthum from native areas. Such study would help uncover its full therapeutic potential and possibly lead to the development of alternative pharmaceuticals to improve human health. Here, we continue our screening of biological activities of traditionally used native under-studied Amaryllidaceae from Senegal [28,29]. Thus, the current investigation explores the anti-AChE, cytotoxicity, antimicrobial, antiviral, and proinflammatory effects of alkaloid extracts from $P$. trianthum collected in Senegal.

\section{Results}

\subsection{Species Phylogenetic Analysis}

To confirm the species of the bulbs collected and used in this study, we amplified and sequenced DNA from a chloroplastic gene encoding the large chain of ribulose bisphosphate carboxylase $r b c L$ [33]. The P. trianthum rbcL sequence obtained (Appendix AFigure A1) was blasted in the National Center for Biotechnology Information (NCBI) database using BLASTn. Top hits were related to $r b c L$ sequences from Pancratium species, with over $96 \%$ sequence identity. Phylogenetic analysis was carried out using phylogeny.fr [34], with default values, including $r b c L$ sequences from 10 Pancratium species and 1 outgroup, from the species Lilium lancifolium Thunb., an Asparagales that belongs to the Liliaceae instead of the Amaryllidaceae family (Figure 1). Maximum likelihood analysis showed a monophyletic clade of the $r b c L$ sequences from all Pancratium species, including P. trianthum P. illyricum L. rbcL sequences clustered outside this common node, and the outgroup L. lancifolium Thunb. was robustly separated from all Amaryllidacease species. P. trianthum sequences grouped closely with P. canariense Ker-Gawl, P. zeylanicum L., and P. hirtum A. Chev (Figure 1), consistently with a phylogenetic study on Pancratium species of the Mediterranean area, which included sequences from $P$. trianthum collected in Burkina Faso [33]. 


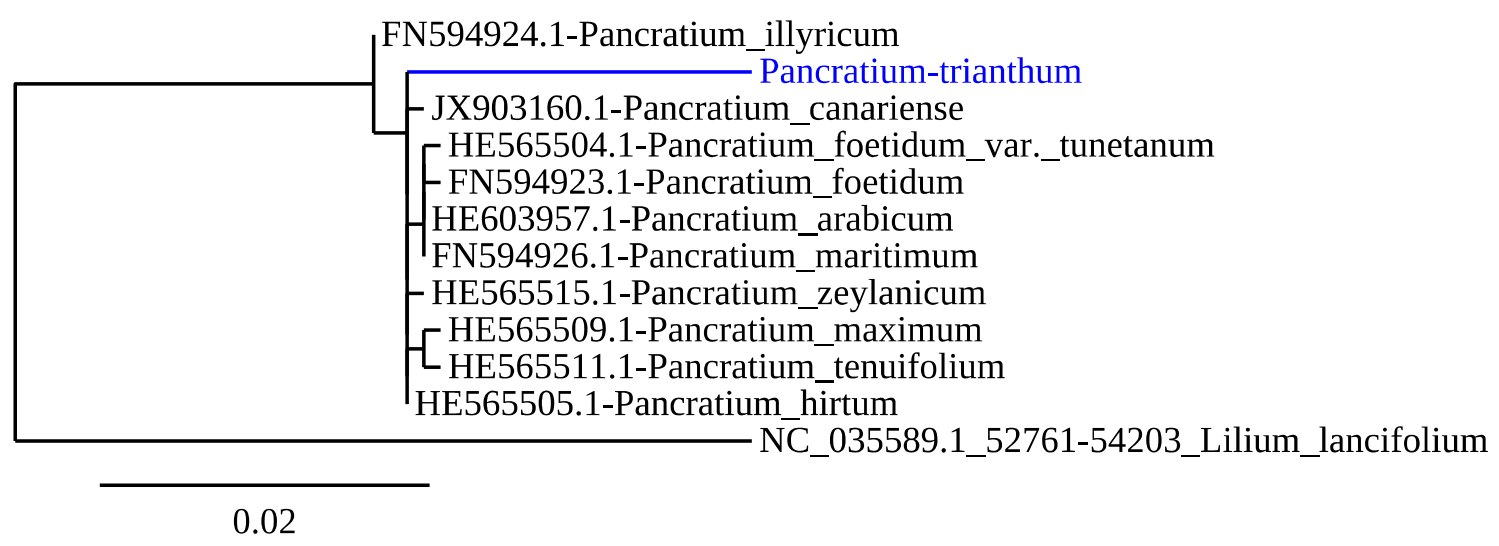

Figure 1. Maximum likelihood phylogenetic analysis of ribulose-bisphosphate carboxylase gene $(r b c L)$ DNA sequences from $P$. trianthum (blue) collected from Senegal. Reference sequences were identified using the GenBank accession numbers. The $r b c L$ sequence from Lilium lancifolum, an Asparagales belonging to Liliaceae but not Amaryllidaceae family, was used as outgroup. The scale of branch length $=0.02$ ( $2 \%$ of genetic variation is shown in the bottom of the tree).

\subsection{Phytochemical Analysis}

Next, an acid-base extraction method was performed on bulbs of $P$. trianthum to isolate alkaloids from other organic compounds based on their acid-base properties. The extraction yielded $0.06 \%$ of the initial bulb biomass extracted. Alkaloid profiles were initially analyzed using chromatographic methods. TLC screening revealed at $254 \mathrm{~nm}$, $365 \mathrm{~nm}$ using Dragendorff's reagent showed the presence of different alkaloids with distinct $\mathrm{R}_{\mathrm{f}}$ values of $0.6,0.4$, and 0.2 (Appendix A-Figure A2).

An optimized high-performance liquid chromatography (HPLC) with photodiode array (PDA) detector was performed to better characterize alkaloids. Three alkaloid standards (i.e., lycorine, galanthamine, and narciclasine) were used. Identification of the alkaloids extracted from bulbs of $P$. trianthum was accomplished by a comparison of the retention time (RT) and absorption spectrum with those obtained for the standards. The RT of lycorine, galanthamine, and narciclasine standards are respectively 7.19, 7.61, and $7.94 \mathrm{~min}$ in the standard solution (data not shown). HPLC analysis of the P. trianthum alkaloid extract showed peaks with RT corresponding to lycorine and narciclasine (Appendix AFigure A2B), although for the latter the absorption spectrum was different compared with the narciclasine standard, suggesting that it was another alkaloid. No RT peak corresponding to galanthamine was detected in P. trianthum alkaloid extracts (Appendix A-Figure 2B). Interestingly, several unidentified peaks appeared with RTs of 6.46, 7.48, 7.92, 8.40, 8.86, and $15.40 \mathrm{~min}$, suggesting potential alkaloids (Appendix A-Figure 2B).<smiles></smiles>

1<smiles></smiles>

2

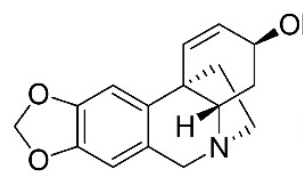

$3 a$

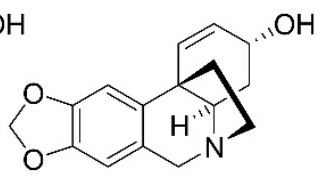

3b

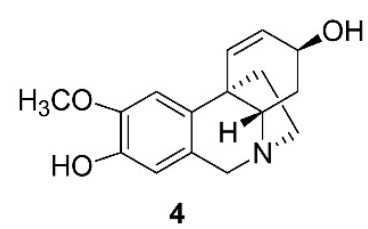

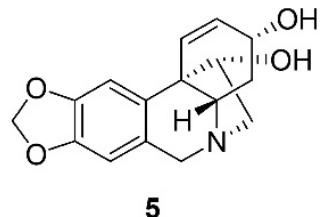<smiles>c1ccc2c(c1)cnc1cc3c(cc12)OCO3</smiles>

Figure 2. Structures of identified AAs confirmed by GC-MS analysis. (1) Lycorine; (2) 11,12Dehydroanhydrolycorine; (3) Vittatine/Crinine; (4) 8-O-Demethylmaritidine; (5) Hamayne; (6) Trisphaeridine. 
P. trianthum alkaloid extracts were further investigated using GC-MS analysis, which led to the identification of six AAs by comparing the GC-MS spectra obtained with those available in NIST 05 database and in the literature (Table 1, Figure 2, Appendix AFigure A3). Two structures could not be attributed to any previously reported alkaloid chemical profile. However, based on the specificity of the extraction method towards the isolation of alkaloids with respect to their physicochemical properties, the two unknown compounds might have been alkaloid. Furthermore, their RT and $\left[\mathrm{M}^{+}\right]$in the GC-MS analysis mimicked Amaryllidaceae alkaloids (Table 1).

Table 1. Alkaloids identified by GC-MS in P. trianthum bulb extracts. Values are expressed as percentages of total ion current (TIC).

\begin{tabular}{|c|c|c|c|c|c|c|}
\hline Ring Type & Alkaloid & {$\left[\mathbf{M}^{+}\right]$} & B.P. & $\begin{array}{l}\text { R.T. } \\
\text { (min) }\end{array}$ & $\begin{array}{l}\text { TIC } \\
(\%)\end{array}$ & Identification Source \\
\hline \multirow{2}{*}{ Lycorine } & Lycorine (1) & 287 & 226 & 25.902 & 5.9 & \multirow{2}{*}{$\begin{array}{c}\text { NIST } 05 \text { Database } \\
\text { [13] }\end{array}$} \\
\hline & 11,12-Dehydroanhydrolycorine (2) & 249 & 248 & 23.811 & 9.1 & \\
\hline \multirow{3}{*}{ Crinine } & Vittatine/Crinine $(\mathbf{3} \mathbf{a} / \mathbf{3} \mathbf{b})$ & 271 & 271 & 21.886 & 3.8 & \multirow{3}{*}{$\begin{array}{c}\text { NIST } 05 \text { Database } \\
\text { [35] } \\
{[36]} \\
\end{array}$} \\
\hline & 8-O-Demethylmaritidine (4) & 273 & 273 & 22.275 & 15.4 & \\
\hline & Hamayne (5) & 287 & 258 & 25.321 & 39.1 & \\
\hline Narciclasine & Trisphaeridine (6) & 223 & 223 & 19.022 & 5.0 & [13] \\
\hline unknown & Unidentified (7) & 287 & 223 & 23.547 & 5.2 & $\mathrm{n} / \mathrm{a}$ \\
\hline unknown & Unidentified (8) & 279 & 278 & 27.682 & 16.4 & $\mathrm{n} / \mathrm{a}$ \\
\hline
\end{tabular}

BP, base peak; RT, retention time (in minute); TIC, total ion current; $n / a$, not applicable.

Altogether, we observed six alkaloids classified according to their structure into lycorine ( $\mathbf{1}$ and $\mathbf{2})$, crinine ( $\mathbf{3 a} / \mathbf{b}, \mathbf{4}$, and $\mathbf{5})$, and narciclasine (6) ring types, together with two unidentified compounds (7 and 8) (Table 1). Compounds (2) and (6) showed ions at $m / z 249$, $248,190,163,123$, and 95 and at $m / z 223,193,164,138$, and 111, respectively, which were not listed in NIST 05 database (Appendix A-Figure A3). However, identical fragmentations were reported in the literature and corresponded to 11,12-dehydroanhydrolycorine (2) and trisphaeridine (6) [13]. Hamayne (5), also not available in NIST 05 database, showed ions at $m / z 287,258,242,186$, and 153 and was identified by similarity with the reported AA from Rhodophiala pratensis [36], while compound (4) displayed ions at $m / z 273,201,175$, 157, 141, and 128, identically to 8-O-demethylmaritidine from Amaryllis belladonna L. [35]. Additionally, an approximation of the relative proportion of identified AAs was estimated as a percentage of the total ion current (TIC) chromatogram. The major compounds (i.e., most abundant) were hamayne (5, 39\% of TIC), 8-O-demethylmaritidine (4, 15\% of TIC), and unidentified compound 8 ( $16 \%$ of TIC). Approximately $58 \%$ of identified alkaloids were crinine-type, $15 \%$ of lycorine-type, and $5 \%$ of the narciclasine-type (Table 1 and Figure 2).

\subsection{In Vitro Anti-AChE Activity}

$P$. trianthum plant preparations are used in folk medicine to treat central nervous system disorders. Therefore, we tested the anti-AChE (human) activity of our extracts. Galanthamine hydrobromide was used at a concentration of $3.7 \mu \mathrm{g} / \mathrm{mL}(10 \mu \mathrm{M})$ as a positive control, and extract dilutions matching DMSO concentrations were used as negative controls to normalize the effect of the solvent (Figure 3A). Galanthamine blocked 59\% of acetylcholinesterase activity. P. trianthum alkaloid extracts inhibited the activity of AChE in a dose-dependent manner at concentrations ranging from 3.9 to $500 \mu \mathrm{g} / \mathrm{mL}$, with an $\mathrm{IC}_{50}$ of $94 \mu \mathrm{g} / \mathrm{mL}$ (Figure 3A). 
A

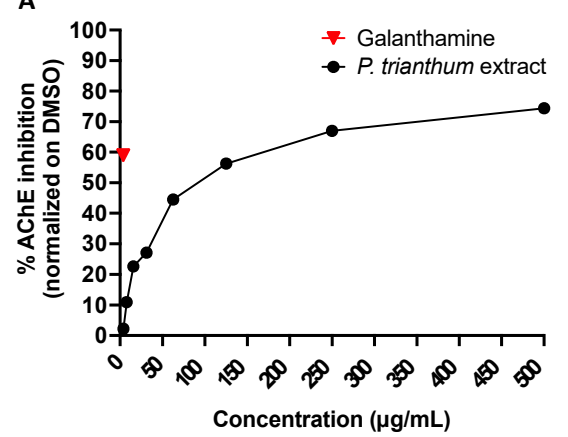

B

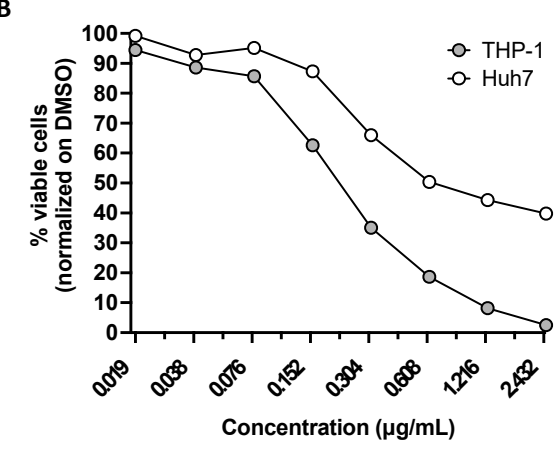

Figure 3. Anti-acetylcholinesterase and cytotoxic activity of AA bulb extracts from Pancratium trianthum (A) Anti-acetylcholinesterase (human)activity. The percentage of inhibition of acetylcholinesterase activity was calculated using DMSO as a negative control. Galanthamine hydrobromide $(3.7 \mu \mathrm{g} / \mathrm{mL}$ or $10 \mu \mathrm{M})$ was used as a positive control. (B) Cellular ATP levels were measured in Huh7 and THP-1 cells to assess viability following $72 \mathrm{~h}$ of incubation.

\subsection{Cytotoxicity Activity}

Several Pancratium species are cytotoxic plants with antiproliferative properties, and the AA lycorine detected in P. trianthum is notoriously cytotoxic [5]. The cytotoxic activity of P. trianthum alkaloid extracts was determined on THP-1 and Huh7 malignant cell lines, and the cytotoxic concentration of the extract causing a $50 \%$ reduction in cell viability $\left(\mathrm{CC}_{50}\right)$ was calculated for each cell line (Figure 3B). Cell viability, as measured through ATP (adenosine triphosphate) levels, was strongly affected by the alkaloid extract in a dose-dependent manner at concentrations ranging from 0.02 to $2.5 \mu \mathrm{g} / \mathrm{mL}$ for both cell lines (Figure 3B). The alkaloid extracts were found to be cytotoxic down to $0.156 \mu \mathrm{g} / \mathrm{mL}$ in THP-1 and $0.313 \mu \mathrm{g} / \mathrm{mL}$ in Huh7, with $\mathrm{CC}_{50}$ values of 0.23 and $0.45 \mu \mathrm{g} / \mathrm{mL}$, respectively (Figure 3B).

\subsection{Antibacterial Activity}

P. trianthum extracts are used in folk medicine as antiseptic to treat wounds, suggesting antimicrobial properties. Here, an agar diffusion assay was used to test the antibacterial activities of $P$. trianthum alkaloid extract. MICs were determined on different bacterial strains (Appendix A-Figure A4). The positive control cefotaxime was active at the tested concentration against $S$. aureus and $P$. aeruginosa, with $22 \mathrm{~mm}$ and $24 \mathrm{~mm}$ diameter growth inhibition areas, respectively. Cefotaxime MIC on S. aureus and P. aeruginosa was $2 \mu \mathrm{g} / \mathrm{mL}$ (data not shown). The highest antibacterial activity of the extracts was observed against S. aureus, with a $20 \mathrm{~mm}$ diameter growth inhibition area at the tested concentration of $16 \mathrm{mg} / \mathrm{mL}$ (Appendix A-Figure A4). Microdilution results confirmed that the alkaloid extract was active against Gram-positive (S. aureus) and against Gram-negative strains (E. coli and P. aeruginosa), though moderately, with MIC values ranging from 1 to $2 \mathrm{mg} / \mathrm{mL}$ (Appendix A-Figure A4), respectively, suggesting that $P$. trianthum holds weak antibacterial properties.

\subsection{Antiviral Activity}

Next, the antiviral activity of alkaloid extracts from $P$. trianthum was measured against lentivirus HIV-1 in THP-1 cells and dengue flavivirus in Huh7 cells (Figure 4). We used a pseudotyped HIV-1 $1_{\mathrm{GFP}}$ vector that infects cells, integrates into the cell genome, and expresses viral proteins and GFP. However, they did not produce nor release infectious viral particles. We treated THP-1 cells with 0.09 to $3.125 \mu \mathrm{g} / \mathrm{mL}$ of $P$. trianthum extract and infected them with $\mathrm{HIV}-1_{\mathrm{GFP}}$ at an $\mathrm{MOI}=1$ (Figure $4 \mathrm{~A}$ ). GFP expression was measured $72 \mathrm{~h}$ post-infection. A dose-dependent inhibition of HIV-1 was observed with increasing concentrations of AAs extract. Weakly cytotoxic (Figure 3B) concentrations of 0.09 and $0.19 \mu \mathrm{g} / \mathrm{mL}$ significantly reduced pseudotyped $\mathrm{HIV}-1_{\mathrm{GFP}}$ infectivity by $28 \%$ and $52 \%$, 
respectively. Interestingly, an $\mathrm{EC}_{50}$ of $0.17 \mu \mathrm{g} / \mathrm{mL}$ was obtained (Figure $4 \mathrm{~A}$ ), a concentration at which viability was $65 \%$ that of the control (Figure 3B).
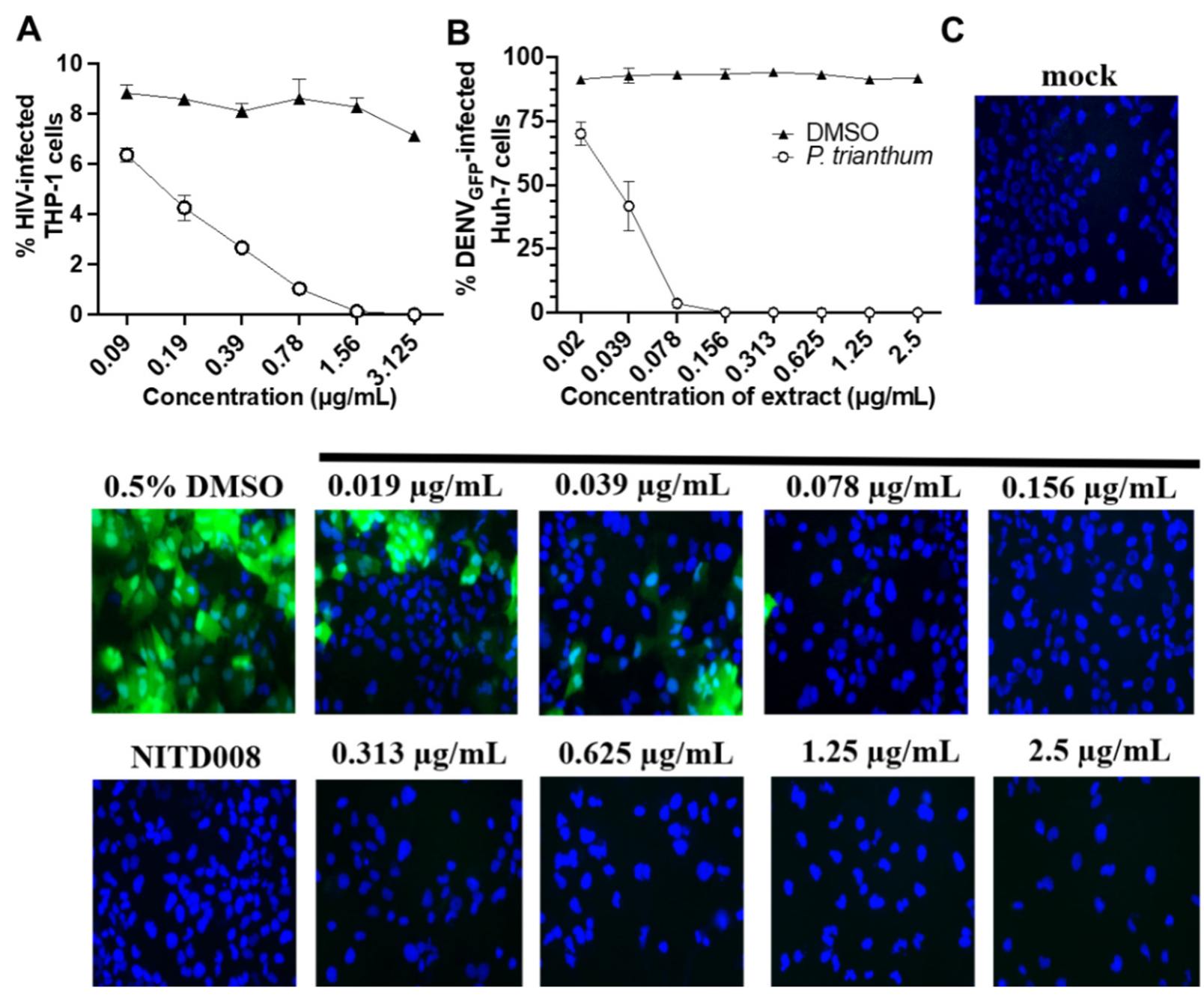

Figure 4. Antiviral activity of P. trianthum alkaloid extracts. (A) Inhibition of HIV-1 infection. THP-1 cells were treated with increasing concentrations of alkaloid extracts and then infected with VSV-G pseudotyped HIV-1 $1_{\mathrm{GFP}}$. (B) Inhibition of $\mathrm{DENV}_{\mathrm{GFP}}$ replication. Huh7 cells treated with $P$. trianthum alkaloid extracts were infected with DENV $\mathrm{GFP}_{\text {and measured by }}$ flow cytometry. For (A,B), infection levels were measured at $72 \mathrm{~h}$ post-infection and shown are means of triplicates with standard deviation; the $x$ axis is in $\log 2$ scale. (C) Inhibition of $\mathrm{DENV}_{\mathrm{GFP}}$ infection in Huh7 cells treated with P. trianthum alkaloid extracts as observed by inverted fluorescence microscopy after $72 \mathrm{~h}$ of infection. Representative images are shown with cell nuclei stained with Hoechst 33342 (blue) and DENV-infected cells (green). DMSO (vehicle) was used as a negative control.

P. trianthum alkaloid extracts were then tested for their ability to inhibit dengue flavivirus $\mathrm{DENV}_{\mathrm{GFP}}$ infection. The $\mathrm{DENV}_{\mathrm{GFP}}$ vector is replication-competent, and thus able to propagate to neighboring cells, and produces GFP upon infection concomitant with translation of its genomic RNA. GFP expression was measured at $72 \mathrm{~h}$ post-infection (Figure $4 \mathrm{~B}, \mathrm{C}$ ). Fluorescent infected cells were visualized on an inverted microscope, and their frequency was measured on a flow cytometer. Adenosine analog NITD008 was used as a positive control at $5 \mu \mathrm{M}$, whereas matching DMSO concentrations were used as negative controls for each dilution. DMSO treatment had no apparent effect on viral replication. Noteworthy, all tested concentrations ranging from 0.019 to $2.5 \mu \mathrm{g} / \mathrm{mL}$ significantly inhibited DENV $\mathrm{GFP}_{\mathrm{F}}$ infection in a dose-dependent manner (Figure 4B, 4C). No infected cells were detected upon treatment with alkaloid extracts at concentrations higher than $0.078 \mu \mathrm{g} / \mathrm{mL}$, as monitored either by microscopy or flow cytometry. Flow cytometry analysis showed that the lowest 
tested extract concentration $(0.019 \mu \mathrm{g} / \mathrm{mL})$ yielded a $20 \%$ reduction in DENV infectivity compared with controls. It also confirmed that DENV replication was nearly completely blocked at $0.078 \mu \mathrm{g} / \mathrm{mL}$, with only $3.3 \%$ of cells infected. These results demonstrate that alkaloids extracted from $P$. trianthum are active against dengue virus at non-cytotoxic concentrations, with an $\mathrm{EC}_{50}$ of $0.029 \mu \mathrm{g} / \mathrm{mL}$ (Figure $4 \mathrm{~B}$ ).

\subsection{Pro-Inflammatory Activity}

The antiviral properties of $P$. trianthum extracts could be associated with a proinflammatory activity. Thus, IFN-type I induction by $P$. trianthum extract was investigated. IFN stimulation was measured in LL171 cell lines containing the interferon-stimulated response element (ISRE)-luciferase reporter. DMXAA, a STING (stimulator of interferon genes) activator, was used as positive control, whereas DMSO was used as negative control. When cells were treated with $P$. trianthum extract at concentrations ranging from 0.015 to $0.5 \mu \mathrm{g} / \mathrm{mL}$, there was no detectable activation of luciferase expression, and hence no IFN production (Figure 5). However, when DMXAA was used in combination with P. trianthum extract, luciferase expression was triggered in a reverse dose-dependent manner. ISRE activity was increased by 2.7 -fold compared with DMXAA treatment alone and by 14.4 -fold compared with DMSO at the three lowest concentrations, $(0.015,0.031$, and $0.0625 \mu \mathrm{g} / \mathrm{mL})$, showing a potentiation between the extract and DMXAA. This suggests that low doses of $P$. trianthum extracts have a synergistic effect when used in combination with IFN-type I inducer DMXAA.

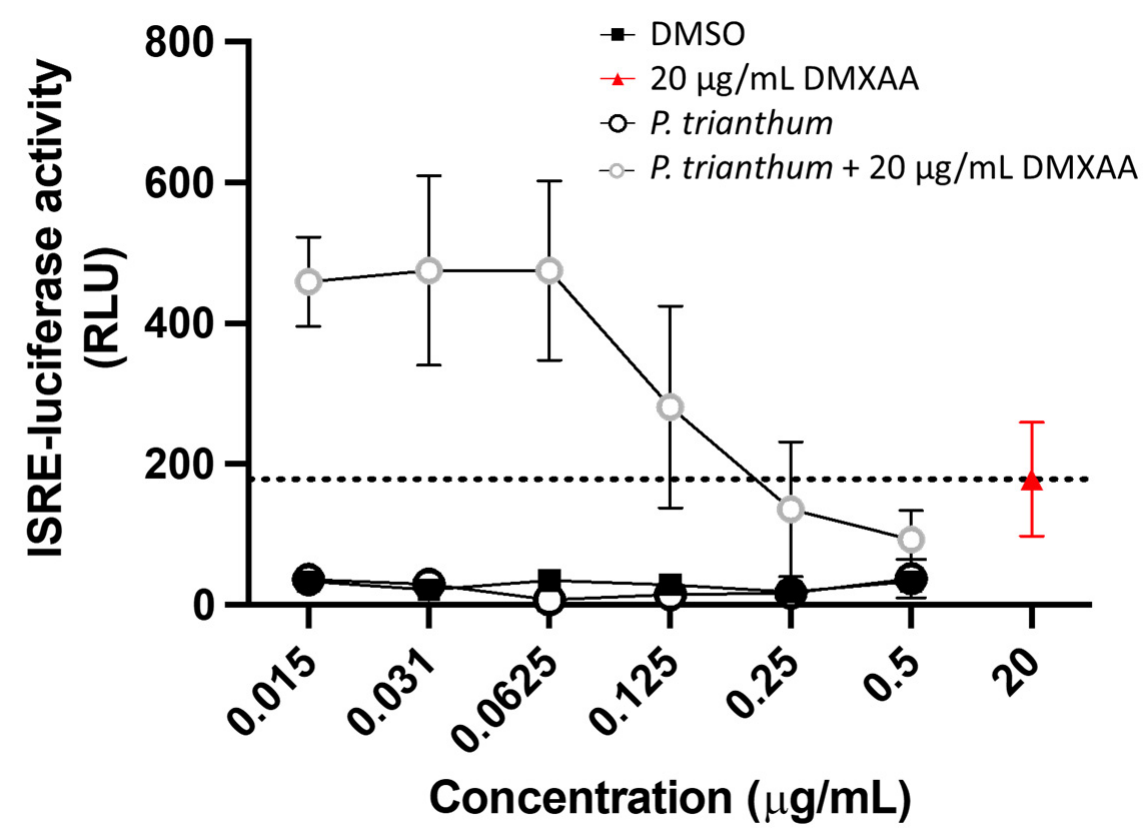

Figure 5. Pro-inflammatory properties of P. trianthum alkaloid extracts. Type I IFN activation was measured through the expression of luciferase driven by the ISRE (IFN-stimulated response element) promoter element and detected by luminescence. LL71 cells were treated with $20 \mu \mathrm{g} / \mathrm{mL}$ DMXAA (a STING activator; red triangle) and P. trianthum bulb extracts at concentrations ranging from 0.015 to $0.5 \mu \mathrm{g} / \mathrm{mL}$, separately (black circles) or in combination with $20 \mu \mathrm{g} / \mathrm{mL}$ DMXAA (gray circles). Matched concentrations of DMSO (black squares) were used as a negative control, respectively. Means of triplicates with standard deviation of luminescence measured $24 \mathrm{~h}$ after treatment are shown. 


\section{Discussion}

In this study, alkaloid preparations extracted from P. trianthum bulbs collected in Senegal were investigated for their biological properties. TLC analysis of crude extracts showed different types of AAs, while HPLC analysis revealed lycorine and narciclasine-like AAs, along with additional peaks suggesting that other AAs were present in P. trianthum extracts. Alkaloid extracts were subjected to GC-MS analysis resulting in the identification of lycorine (1) and vittatine (3a)/ crinine ( $3 \mathbf{b})$ by comparison with their mass spectra available in the NIST05 database and of 11,12-dehydroanhydrolycorine (2), 8-O-demethylmaritidine (4), hamayne (5), and trisphaeridine (6) by comparing with the mass spectra available in the literature. As vittatine (3a) only differs from crinine $(\mathbf{3} \mathbf{b})$ in the position of the 5,10b-ethano bridge, which can only be distinguished by a circular dichroism spectrum, (3) could be either one or the other crinine-type of AAs. Using the percentage of TIC as approximative quantification, we observed that crinine- and lycorine-type AAs were the most abundant AAs in P. trianthum bulb extracts. Unidentified compounds represented approximately $16 \%$ of the crude extracts and should be isolated in future studies using additional chromatography techniques. In contradiction to a previous report [31], but consistent with the HPLC analysis, galanthamine, hippeastrine, hordenine, pancratine, tazettine, and trianthine were not detected in P. trianthum extracts. This difference could be explained by the fact that plants were not collected from the same environment as AA production and could be affected by environmental and climatic conditions. In addition, our study specifically targeted alkaloids extracted from bulb.

In Senegal, leaves and bulbs of $P$. trianthum are used to treat central nervous system disorder, heal wounds, and soothe irritations [17], suggesting potential anti-AChE, antibacterial, and antiviral activity. The AChE inhibitory activity is generally attributed to galanthamine and lycorine-types AAs $[37,38]$. Hamayne (5) detected in the extract was also previously reported to have weak AChE inhibitory activity [39]. In our study, P. trianthum alkaloid extracts weakly inhibited $\mathrm{AChE}$ activity in a dose-dependent manner, with concentrations ranging from 3.9 to $500 \mu \mathrm{g} / \mathrm{mL}$. Although the observed levels of inhibition were lower than previously observed in P. maritimum L. [40,41], they were consistent with the lack of detection of galanthamine-type alkaloids in our extracts.

Previous studies showed that lycorine (1), the main phenanthridine AA in our extract, displayed a strong antitumor activity $[42,43]$. P. trianthum alkaloid extracts were increasingly cytotoxic at concentrations above $0.313 \mu \mathrm{g} / \mathrm{mL}$ for hepatocarcinoma Huh7 cells and $0.156 \mu \mathrm{g} / \mathrm{mL}$ for monocytic leukemia THP- 1 cells, consistent with the presence of the cytotoxic AA lycorine. P. trianthum bulb alkaloid extracts appeared to be more cytotoxic than reported from other Pancratium species such as P. illyricum L., but different cell lines were used, and the contents of their alkaloids are different [44].

Crinine- and lycorine-types have also been associated with antibacterial properties [45-47]. Hence, we tested the antibacterial potency of the extract. All tested strains were sensitive to high concentrations of the alkaloid extract. The Gram-positive species S. aureus was more strongly inhibited than Gram-negative species (E. coli and P. aeruginosa). This activity could be specific to limited Pancratium species, such as P. illyricum L. alkaloid extracts that were described to be completely ineffective against both Gram-positive and Gram-negative bacteria [42]. Thus, detected vittatine (3a)/crinine (3b) and lycorine (1) might contribute to the antimicrobial effect of the alkaloid extract.

While the rate of new HIV-1 infection is declining and the coverage of people receiving antiretroviral therapy (ART) is growing in Senegal, prevalence remains high in specific populations such as sex workers ( $4.8 \%$ infected, of which $28.3 \%$ are under ART) and men who have sex with men $(27.6 \%$, of which $37.8 \%$ are under ART) [48]. Because of the high prevalence and the constant threat of the virus escaping treatment due to mutation-associated resistance, there is still a strong impetus to identify new antiviral compounds. In some studies, lycorine (1) has been shown to inhibit HIV-1 infection [49,50]. Our results show that low concentrations of $P$. trianthum extracts reduce HIV-1 infectivity levels, although full inhibition was only observed at cytotoxic concentrations. To continue our 
screening of P. trianthum antiviral potential, we then measured its effect on DENV infection. Several flaviviruses cocirculate in tropical and subtropical areas of the world and threaten the lives of hundreds of millions of people, making the development of broad-spectrum anti-flaviviral compounds a necessity. Previous studies showed that some Amaryllidaceae extracts present anti-dengue potential [28,51], and the AA lycorine (1) detected in this study potently inhibits flaviviruses in in vitro and in vivo models [52-54]. Here, we show that non-cytotoxic concentration of $P$. trianthum extracts ranging from 0.019 to $0.156 \mu \mathrm{g} / \mathrm{mL}$ displayed strong antiviral activity, with full inhibition at $0.156 \mu \mathrm{g} / \mathrm{mL}$. When compared with our recent study on Crinum jagus (J. Thomps.) Dandy extract, the P. trianthum antiviral activity was 8.6-fold higher ( $\mathrm{IC}_{50}=0.25 \mu \mathrm{g} / \mathrm{mL}$ vs. $0.029 \mu \mathrm{g} / \mathrm{mL}$, respectively) [28]. Interestingly, low doses of $P$. trianthum extracts also displayed potentiation effects with IFN-inducers. Thus, purification of alkaloids from P. trianthum could possibly lead to the discovery of strong antiviral compounds.

\section{Materials and Methods}

\subsection{Plant Materials, Chemicals, and Species Identification}

P. trianthum bulbs were collected in Saint Louis, Senegal $\left(16^{\circ} 3^{\prime} 19.35^{\prime \prime} \mathrm{N}, 16^{\circ} 25^{\prime} 42.25^{\prime \prime} \mathrm{W}\right)$, in December 2018. Collected plants were taxonomically identified using the database at the Herbarium of IFAN at the Université Cheikh Anta Diop of Dakar.

In addition, genomic DNA was extracted from dried roots of $P$. trianthum using the DNeasy plant mini kit (QIAGEN) according to the manufacturer's instructions. Yield and purity of total extracted DNA were quantified with a Nanodrop (IMPLEN, QC, CA) and stored at $-20^{\circ} \mathrm{C}$ for later use. Ribulose-bisphosphate carboxylase gene $(r b c L)$ DNA barcode of $P$. trianthum was amplified by PCR using TaKaRa's PrimeSTAR GXL Premix kit with primers (F-5'-GGATTACCAGCCTTGATCG- $3^{\prime}$ and R-5'-TTCACGAGCAAGATCACGTC$\left.3^{\prime}\right)$ [33]. The PCR mixture $(20 \mu \mathrm{L})$ contained $2 \mu \mathrm{L}$ of genomic DNA, $10 \mu \mathrm{L}$ Takara mix, $0.4 \mu \mathrm{L}$ of each primer $(10 \mu \mathrm{M}$, forward and reverse primers), and $7.2 \mu \mathrm{L}$ of ultrapure-DNase free water. The thermocycler program consisted of an initial denaturation step $\left(98^{\circ} \mathrm{C}\right.$ for $2 \mathrm{~min}$ ), followed by 30 amplification cycles $\left(98^{\circ} \mathrm{C}\right.$ for $10 \mathrm{~s}, 55^{\circ} \mathrm{C}$ for $15 \mathrm{~s}$, and $68^{\circ} \mathrm{C}$ for $75 \mathrm{~s})$. After PCR, $5 \mu \mathrm{L}$ of amplified product was loaded on a $1 \%$ agarose gel, and specific size amplicons (1044 bp) were sequenced using both forward and reverse primers.

\subsection{Crude Alkaloids Extraction and TLC Analysis}

Alkaloid extraction was achieved using the method described in [55]. P. trianthum dried bulbs (50 g) were crushed manually and macerated for $24 \mathrm{~h}$ with $\mathrm{MeOH}$ at room temperature, and the macerate was filtered and concentrated under reduced pressure. This crude extract was acidified with sulphuric acid $(2 \%)$ at $\mathrm{pH}=2$ and extracted successively with $\mathrm{Et}_{2} \mathrm{O}(4 \times 200 \mathrm{~mL})$ and $\mathrm{EtOAc}(4 \times 200 \mathrm{~mL})$ to remove neutral material. The resulting acidic aqueous solution was basified with concentrated ammonia (25\%) up to $\mathrm{pH}=10$, then extracted with EtOAc $(4 \times 200 \mathrm{~mL})$ and evaporated. Alkaloid extracts were then dissolved in EtOAc at a final concentration of $1 \mathrm{mg} / \mathrm{mL}$ and used for thin-layer chromatography (TLC). Qualitative analysis of alkaloids was performed on TLC silica gel $60 \mathrm{~F}_{254}$ aluminum sheets $20 \times 20 \mathrm{~cm}$, (Merck, Darmstadt, Germany). The TLC plate was eluted with $\mathrm{MeOH}$ : EtOAc $(25: 75 v / v)$, dried at room temperature, observed under UV light at $254 \mathrm{~nm}$ and $365 \mathrm{~nm}$, and then revealed with Dragendorff reagent [56,57].

\subsection{HPLC-PDA and GC-MS Analysis of Alkaloid Extracts}

For the HPLC analysis, we followed the method described by [58], with some modifications. The alkaloid extract was dissolved in $\mathrm{MeOH}$ at a final concentration $0.5 \mathrm{mg} / \mathrm{mL}$. Afterward, $10 \mu \mathrm{L}$ of each sample and $10 \mu \mathrm{L}$ of $100 \mathrm{ppm}$ of each standard (galanthamine, narciclasine (both from Tocris Bioscience, Bristol, UK), and lycorine (Sigma-Aldrich, St. Louis, MO, USA)) were injected and analyzed on a Shimadzu Prominence-I LC-2030C with diode array detector (PDA). For separation, the Kinetex C18 column $\left(150 \times 4.6 \mathrm{~mm}^{2}, 5 \mu \mathrm{m}\right.$ particle size; Phenomenex) was used. HPLC oven temperature was set at $40^{\circ} \mathrm{C}$. A gradient elution 
with two solvents, $1 \%$ ammonium acetate buffer (solvent A) and 100\% acetonitrile (solvent B), was used. The 90:10 B to A solvent gradient ratio was first maintained for $10 \mathrm{~min}$, then shifted to 69:31 over $1 \mathrm{~min}, 70: 30$ over $4 \mathrm{~min}$, and finally 90:10 over $3 \mathrm{~min}$. After $18 \mathrm{~min}$, A was increased to $90 \%$, and B was reduced to $10 \%$ for $5 \mathrm{~min}$, yielding a total run time of 23 min.

For the GC-MS analysis, $1 \mathrm{mg} / \mathrm{mL}$ of alkaloid extract in $\mathrm{MeOH}$ was directly injected into the GC-MS (Agilent Technologies 6890N GC coupled with 5973N inert MSD) in EI (Electron Ionization) mode at $70 \mathrm{eV}$. The temperature ramp used is described as follows: temperature was set at $100{ }^{\circ} \mathrm{C}$ for $2 \mathrm{~min}$, followed by $100-180{ }^{\circ} \mathrm{C}$ at $15^{\circ} \mathrm{C} \mathrm{min}-1,180-300{ }^{\circ} \mathrm{C}$ at $5{ }^{\circ} \mathrm{C} \mathrm{min}{ }^{-1}$, and a $10 \mathrm{~min}$ hold at $300{ }^{\circ} \mathrm{C}$. Injector and detector temperatures were set at $250{ }^{\circ} \mathrm{C}$ and $280^{\circ} \mathrm{C}$, respectively, and the flow rate of carrier gas $(\mathrm{He})$ was $1 \mathrm{~mL} \mathrm{~min}^{-1}$. A split ratio of 1:10 was applied, and the injection volume was $1 \mu \mathrm{L}$ [59]. Alkaloids were identified by comparison with the 2005 National Institute of Standards database based on matching mass spectra, GC-MS spectra of authentic compounds previously isolated and identified by other spectroscopic methods in these species, or with data obtained from the literature. The total ion current (TIC) percentage provided in Table 1 was connotated with the proportion of each compound in the extract as a semi-quantitative estimate. The area of the GC-MS peaks depends both on the concentration of the related compounds and their relative signal intensity in MS.

\subsection{In Vitro Acetylcholinesterase (AChE) Inhibition Assay}

In vitro inhibition of electric eel, Electrophorus electricus, AChE by the alkaloid extract of P. trianthum was assessed using the method described in [29].

\subsection{Cell Lines}

Human hepatocarcinoma cell line Huh7 (kindly provided by Professor Hugo Soudeyns, CHU Sainte-Justine, Montréal, QC, Canada) and murine LL171 reporter cells [60] were maintained in Dulbecco's modified Eagle's medium high glucose (DMEM), supplemented with $10 \%$ fetal bovine serum (FBS) and 1\% penicillin-streptomycin (PS, all from Cytiva Hyclone) solution. Human acute monocytic leukemia cell line THP-1 was grown in Roswell Park Memorial Institute Medium (RPMI) containing 10\% FBS and 1\% PS. All cells were maintained at $37^{\circ} \mathrm{C}$ and $5 \% \mathrm{CO}_{2}$.

\subsection{Cytotoxicity Assay}

Cell viability was evaluated using the Cell-Titer GLO assay kit (Promega, Madison, WI, USA). Briefly, $50 \mu \mathrm{L}$ of $7.5 \times 10^{3} \mathrm{Huh} 7$ cells/well or $2 \times 10^{4} \mathrm{THP}-1$ cells/well was seeded in 96-well dark plates and cultured for $16 \mathrm{~h}$. Then, they were treated with $50 \mu \mathrm{L}$ of alkaloid extract at concentrations (<0.5\% DMSO) ranging from 0.019 to $2.5 \mu \mathrm{g} / \mathrm{mL}$ for $72 \mathrm{~h}$. Afterward, $100 \mu \mathrm{L}$ of room temperature Cell-Titer GLO reagent was added in each well to room temperature-equilibrated plates. Plates were rocked for $2 \mathrm{~min}$, and the luminescence signal was measured 10 min later using a microplate spectrophotometer (Synergy H1, Biotek, QC, Canada). The percentage of viable cells was calculated at each concentration. All assays were performed in triplicate.

\subsection{Bacteria and Viruses}

Three bacteria species including the Gram-positive strain Staphylococcus aureus ATCC 29213 and two Gram-negative strains, Escherichia coli ATCC 35218 and Pseudomonas aeruginosa ATCC 27853, were obtained from the American Type Culture Collection (ATCC) and from the Laboratory of Bacteriology-Virology at Aristide Le Dantec Hospital (Senegal). Bacteria were cultured in Mueller Hinton (MH) agar media and incubated at $37^{\circ} \mathrm{C}$ for $24 \mathrm{~h}$ before use. 
Dengue virus vectors expressing green fluorescent protein (DENV $\left.{ }_{\mathrm{GFP}}[61]\right)$ and singleround infection pseudotyped human immunodeficiency virus-1 (HIV-1 $1_{\mathrm{GFP}}$ [62]) were used to investigate antiviral activity. The multiplicity of infection (MOI) of HIV-1 $1_{\text {GFP }}$ was assessed by measuring the infectivity of serially diluted vector preparation in Crandell-

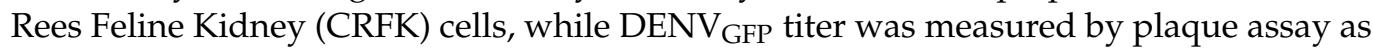
described in [28].

\subsection{Agar Diffusion Assay}

Antimicrobial activity of the alkaloid extract was first studied using the agar diffusion assay method. A suspension of each strain was prepared into sterile physiological water to obtain a final inoculum, estimated at $1.5 \times 10^{8} \mathrm{CFU} / \mathrm{mL}$ according to $0.5 \mathrm{McFarland}$ turbidity. Alkaloid extracts were dissolved in DMSO at $16 \mathrm{mg} / \mathrm{mL}$. For the assay, a sterile cotton swab was immersed in the inoculum, then wrung on the wall of the tube. The swab was then spread over on the agar plate to obtain uniform inoculum. Wells were made on Mueller Hinton agar plates using a sterile cylinder of $6 \mathrm{~mm}$ diameter. Plates were dried for $5 \mathrm{~min}$, and $100 \mu \mathrm{L}$ of alkaloid extract was deposited. Plates were incubated at $37^{\circ} \mathrm{C}$ for 18-24 h. The antibacterial activity of the alkaloid extract was then measured as an inhibition zone surrounding the well [63]. Cefotaxime was used as a positive control.

\subsection{Broth Dilution Method for Determination of Minimal Inhibitory Concentration (MIC)}

Microdilution of alkaloid extracts from $P$. trianthum was performed using a modification of Balouiri et al. [64]. Dilutions were started by pipetting $100 \mu \mathrm{L}$ of alkaloid extract into the first well of a 96-well plate containing $100 \mu \mathrm{L}$ of $\mathrm{MH}$ broth. Serial dilutions were then carried out to obtain a range of concentrations between 0.03 to $8 \mathrm{mg} / \mathrm{mL}$. Then, $10 \mu \mathrm{L}$ of bacterial suspension cultures was added into each well. Plates were incubated at $37^{\circ} \mathrm{C}$ for $24 \mathrm{~h}$. The MIC (minimal inhibitory concentration) was determined as the lowest concentration of the alkaloid extract that completely suppressed the growth of microorganisms (which was determined by the wells showing no turbidity). Tested bacteria were exposed to broth without the alkaloid extract as a control.

\subsection{In Vitro $D E N V_{G F P}$ Infectivity Assay}

Briefly, Huh7 cells were seeded at $1.5 \times 10^{4}$ cells per well in 48-well plates, cultured for $16 \mathrm{~h}$, and then pretreated with concentrations of $P$. trianthum alkaloid extract ranging from 0.02 to $2.5 \mu \mathrm{g} / \mathrm{mL}$, infected with $\mathrm{DENV}_{\mathrm{GFP}} 2 \mathrm{~h}$ later at a multiplicity of infection (MOI) of $0.1 \mathrm{PFU} /$ cell and incubated at $37^{\circ} \mathrm{C}$ for $72 \mathrm{~h}$. Green fluorescence signal of infected cells was visualized and pictured on a Axio Observer microscope (Carl Zeiss, Inc., Toronto, ON, Canada). Cells were trypsinized and fixed in $4 \%$ aqueous formaldehyde, then processed for flow cytometry analysis of GFP expression using a FC500 MPL cytometer (Beckman Coulter, Inc., CA) coupled with the FCS Express 6 software (De Novo Software, Pasadena, CA, USA). The adenosine analogue NITD008 $(10 \mu \mathrm{M})$ was used as a positive control for inhibition of DENV infection. Extract-matched concentrations of DMSO were used as a negative control. All assays were performed in triplicate at least twice.

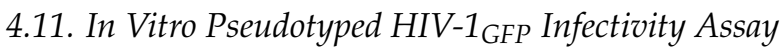

The antiretroviral activity of $P$. trianthum Herb.'s crude extract was evaluated using pseudotyped HIV-1 $1_{\mathrm{GFP}}$ in THP-1 cells. THP- 1 cells were seeded at $2.0 \times 10^{4}$ cells per well in 96-well plates and incubated overnight. Cells were treated with 5 concentrations of

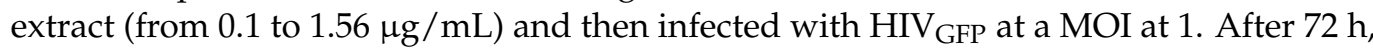
the percentage of infected cells was measured using a FC500 MPL cytometer (Beckman Coulter, Inc., Brea, CA, USA) and analyzed using FlowJo software (FlowJo LLC, Ashland, OR, USA). Matched concentrations of DMSO were used as a negative control. All assays were performed in triplicate. 


\subsection{In Vitro Proinflammatory Assay}

In vitro proinflammatory assay was performed using the Luciferase Assay Systems kit (Promega). Briefly, $200 \mu \mathrm{L}$ LL171 cells was seeded at $1.5 \times 10^{4}$ cells/well in 96-well plates and cultured for $16 \mathrm{~h}$. Then, the medium was replaced with medium containing alkaloid extract at a concentration ranging from 0.015 to $0.5 \mu \mathrm{g} / \mathrm{mL}$ for $24 \mathrm{~h}$. The supernatant was removed, and cells were rinsed with PBS. Then, $30 \mu \mathrm{L}$ of lysis buffer was added and homogenized. Afterward, $20 \mu \mathrm{L}$ of each lysate was transferred into 96-well opaque plates, $100 \mu \mathrm{L}$ of Luciferase Assay Reagent (Promega) was added, and luminescence was measured at $480 \mathrm{~nm}$ using a microplate spectrophotometer (Synergy H1, Biotek, Quebec, Canada). 5,6-Dimethylxanthenone-4-acetic acid (DMXAA, $20 \mu \mathrm{g} / \mathrm{mL}$ ) was used as a positive control. All assays were performed in triplicate.

\section{Conclusions}

In conclusion, this study led to the detection of eight AAs, six of which were identified by GC-MS, in the alkaloid extract of P. trianthum Herb.'s bulb collected in Senegalese flora. Based on the traditional use of the Pancratium genus for wound-healing, central nervous system disorder, and antiproliferative and antiviral purposes, the alkaloid extracts prepared were screened for antibacterial, anti-AChE, cytotoxic, and antiviral properties. Alkaloid extracts displayed antibacterial effect, with MIC values of $1 \mathrm{mg} / \mathrm{mL}$ for $S$. aureus and $2 \mathrm{mg} / \mathrm{mL}$ for E. coli and P. aeruginosa but weak anti-AChE property $\left(\mathrm{IC}_{50}=94 \mu \mathrm{g} / \mathrm{mL}\right)$. Interestingly, the $P$. trianthum extracts displayed strong and moderate antiviral activity against $\mathrm{DENV}_{\mathrm{GFP}}$ and pseudotyped HIV-1 $1_{\mathrm{GFP}}$, with $\mathrm{EC}_{50}$ of 0.029 and $0.17 \mu \mathrm{g} / \mathrm{mL}$, respectively. We conclude that the medicinal properties of $P$. trianthum may be attributed to its alkaloid components and provide the scientific basis for its traditional use to prevent infections. Finally, this study supports the role of Amaryllidaceae species as a source of compounds with potential therapeutical applications.

Author Contributions: S.K. designed and executed experiments, analyzed data, and prepared the manuscript. N.M. designed and executed experiments, analyzed data, revised the manuscript, and supervised the work. A.D., I.S. and C.S.B.B. helped S.K. to conduct antibacterial activity. L.B. provided viruses and cells and revised the manuscript. K.L. and G.P. provided the materials and helped design and execute experiments related to pro-inflammatory properties with S.K., B.D. and S.R. conducted and analyzed the GC-MS study with S.K., M.S. helped design the experiments, analyzed data, revised the manuscript, and co-supervised S.K., I.D.-P. secured fund acquisition, designed experiments, analyzed data, revised the manuscript, and supervised the entire research work. All authors have read and agreed to the published version of the manuscript.

Funding: This work was funded by the Canada Research Chair on plant specialized metabolism Award No 950-232164 to Isabel Desgagné-Penix. Many thanks are extended to the Canadian taxpayers and to the Canadian government for supporting the Canada Research Chairs Program.

Institutional Review Board Statement: Not applicable.

Informed Consent Statement: Not applicable.

Data Availability Statement: Not applicable.

Acknowledgments: The authors would like to thank Fatma Meddeb, Manel Ghribi, and all the lab members for their technical support and useful advice. Warm thanks to Professors Hugo Germain, Céline Van Themsche, and Carlos Reyes-Moreno for kindly providing cells and cell culture equipment. The authors also wish to acknowledge Sebastien Santini (CNRS/AMU IGS UMR7256, France) and the PACA Bioinfo platform (supported by IBISA) for the availability and management of the phylogeny.fr website used to confirm plant species.

Conflicts of Interest: The authors declare no conflict of interest.

Sample Availability: Samples of the dried bulbs are limited but available from the authors. 


\section{Appendix A}

$>$ Pt_rbcL

CATTGAGGCCGTTGTTGGGGAAGGAAATCAATATATTGCTTATGTAGCTTATCCTT TAGACCTTTTTGAAGAAGGTTCTGTTACTAACATGTTTACTTCCATTGTGGGTAAT GTATTTGGTTTCAAAGCCCTACGAGCTCTACGTCTGGAGGATCTGCGAATTCCCC CTGCTTATTCCAAAACTTTCCAAGGCCCGCCCCATGGCATCCAATCTGAAAGAGA TAAATTGAACAAGTATGGTCGTCCCCTATTGGGATGTACTATTAAACCAAAATTG GGATTATCCGCAAAAAACTACGGTAGAGCGGTTTATGAATGTCTACGCGGTGGG CTTGATTTTACCAAGGATGACGAAAACGTGAACTCCCAACCTTTTATGCGTTGGA GAGACCGTTTCTTATTTTGTGCTGAAGCAATTTATAAAGCGCAAGCCGAAACAGG TGAAATCAAAGGACATTACTTGAATGCAACTGCGGGTACATGTGAAGAAATGAT CAAAAGGGCCGTATTTGCCAGAGAATTGGGAGTTCCTATCGTAATGCATGACTAC TTAACTGGGGGATTCACTGCAAATACTAGTTTGGCTTTTTATTGCCGCGACAACG GTCTACTTCTTCACATCCACCGCGCAATGCATGCAGTTATTGATAGACAGAAAAA TCATGGTATGCATTTTCGTGTACTAGCTAAAGCATTACGTATGTCTGGTGGAGATC ATATTCACGCTGGTACAGTGTAAGGTAAACTGGAAGGGGAACGCGAGATGACTT TAGGTTTTGTTGATTTATTACGTGATGATTATATTGAAAAAGACCGAAGTCGTGGT ATTTTTTTCACTCAAGATTGGGTTTCTATGCCAGGTGATCTGCGTATTGCCTATGG GGGTATTCATGTTTGGCATATGCCGCCCTACGGAATCTTTGGGATGATTCCGTACT ACAGTTCGGTGGAGGAACTTTAGGACACCCTTGGGGAAATGCACCTGGTGCGTA GCTAATCGGGTAGCTTTAGAAGCGATATAGA

Figure A1. P. trianthum $r b c L$ sequence amplified from bulbs and obtained from Sanger sequencing.

A
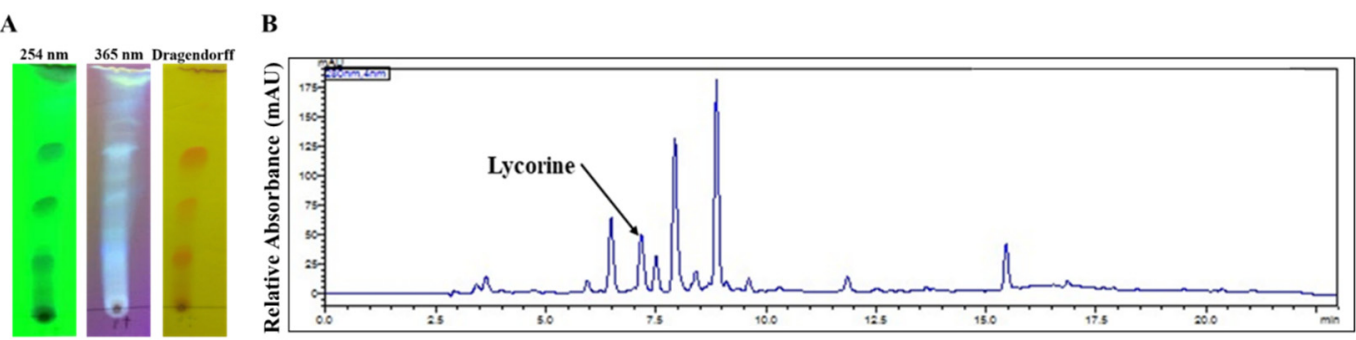

Figure A2. Phytochemical analysis of P. trianthum alkaloid extracts. (A) TLC revealed by UV at $254 \mathrm{~nm}$ and $365 \mathrm{~nm}$, using Dragendorff's reagent. (B) HPLC-DAD chromatogram of $P$. trianthum alkaloid extract at $280 \mathrm{~nm}$. The peak corresponding to lycorine is indicated with an arrow. 
$\underset{\substack{\text { Lycorine } \\ \text { Abundance }}}{\mathbf{1})}$

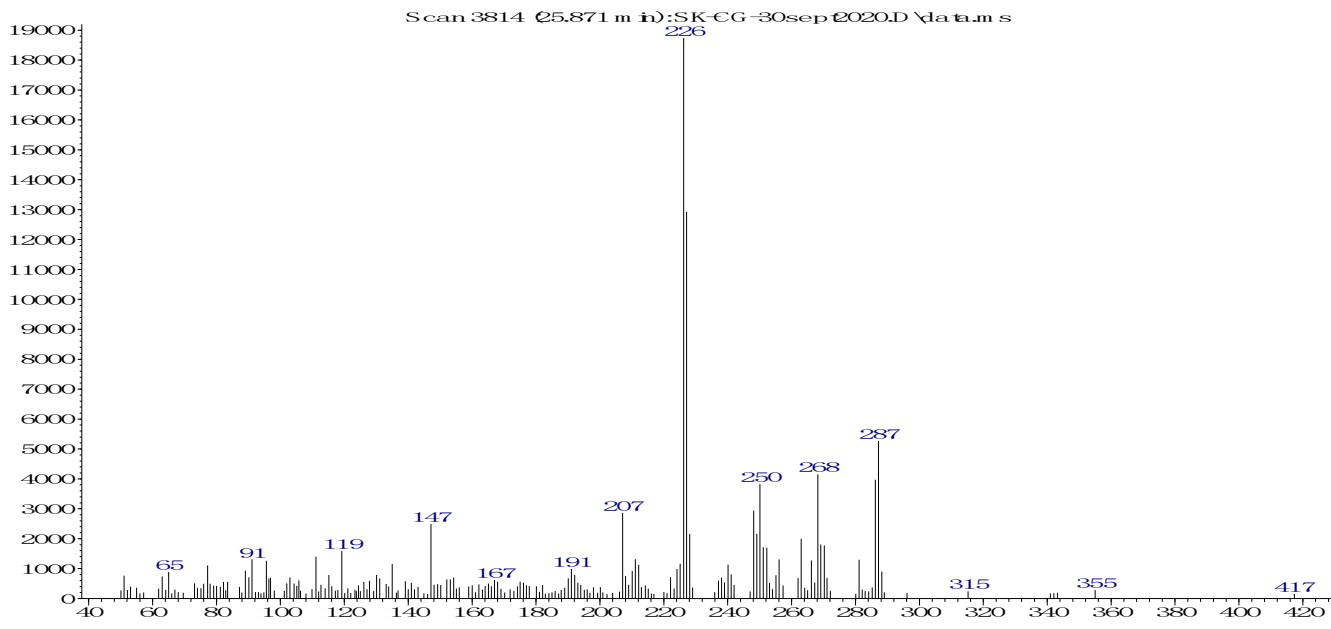

11,12-Dehydroanhydrolycorine (2)

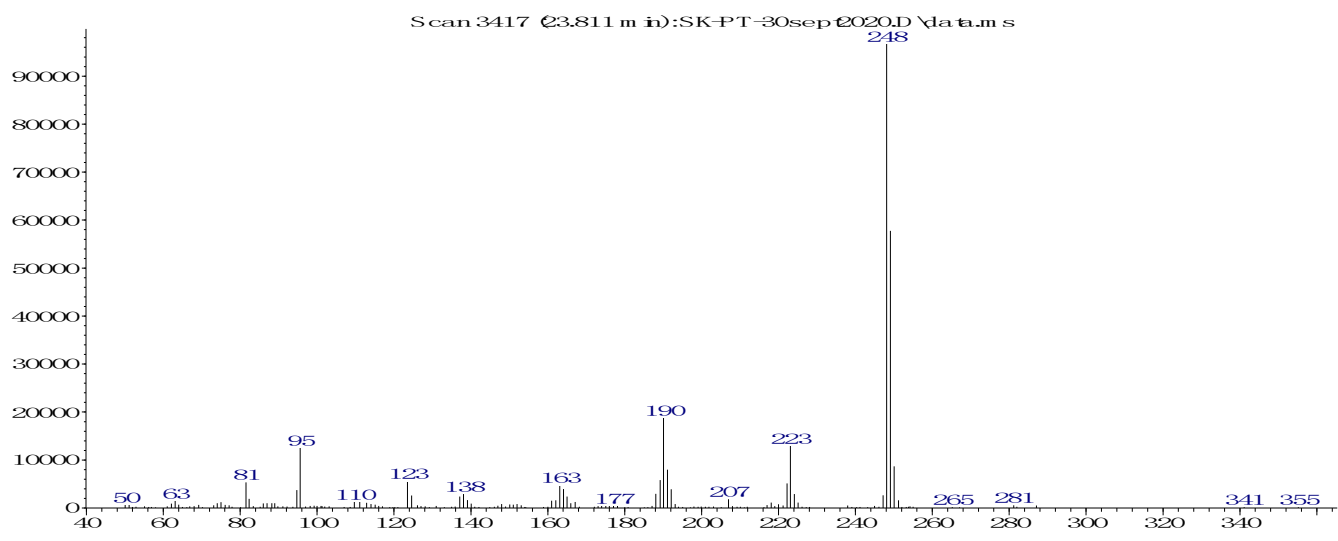

Vittatine/crinine (3)

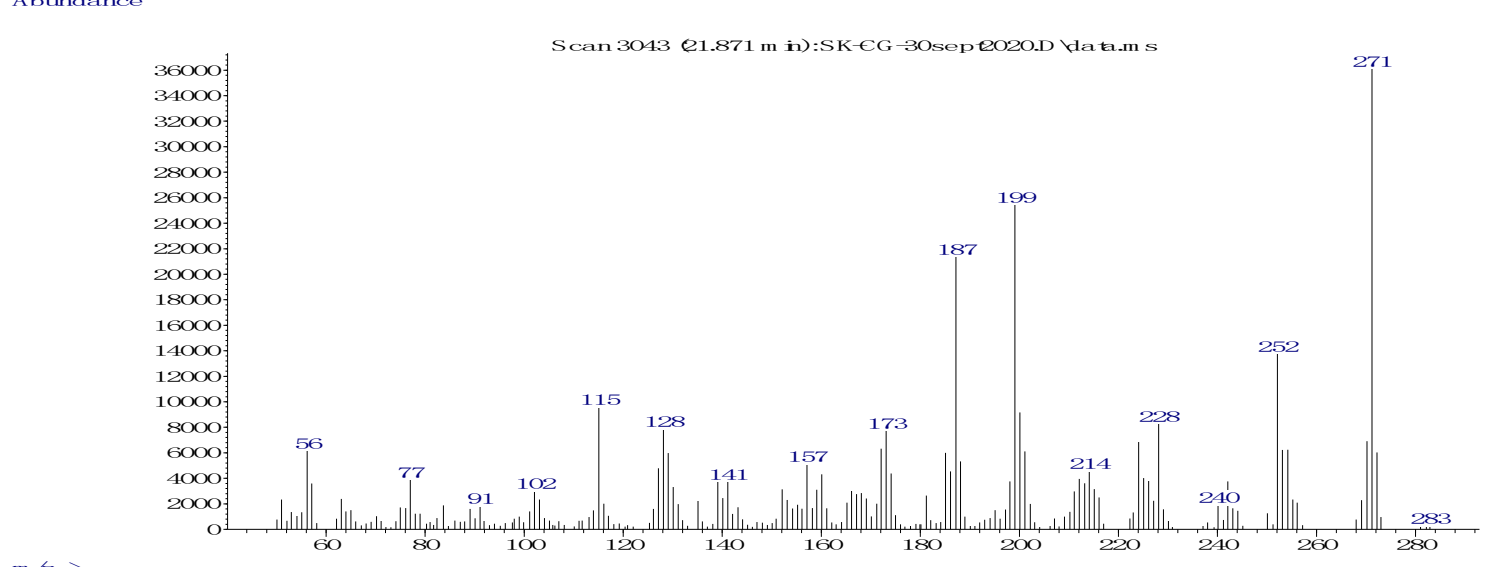

Figure A3. Cont. 
8-O-Demethylmaritidine (4)

Abundance

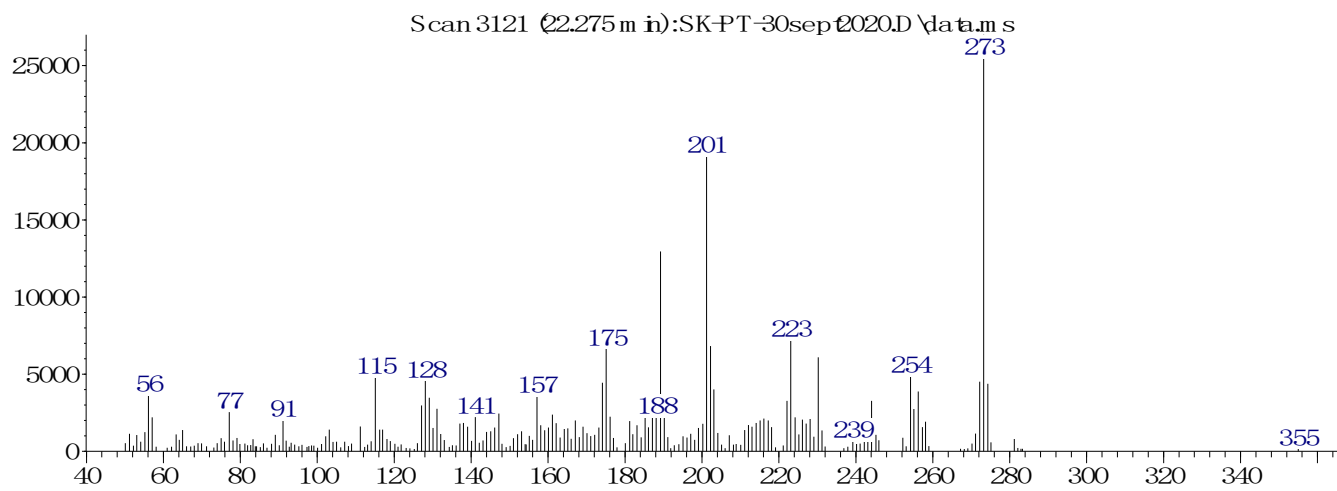

$\mathrm{m} / \mathrm{z} \rightarrow$

Hamayne (5)

Abundance

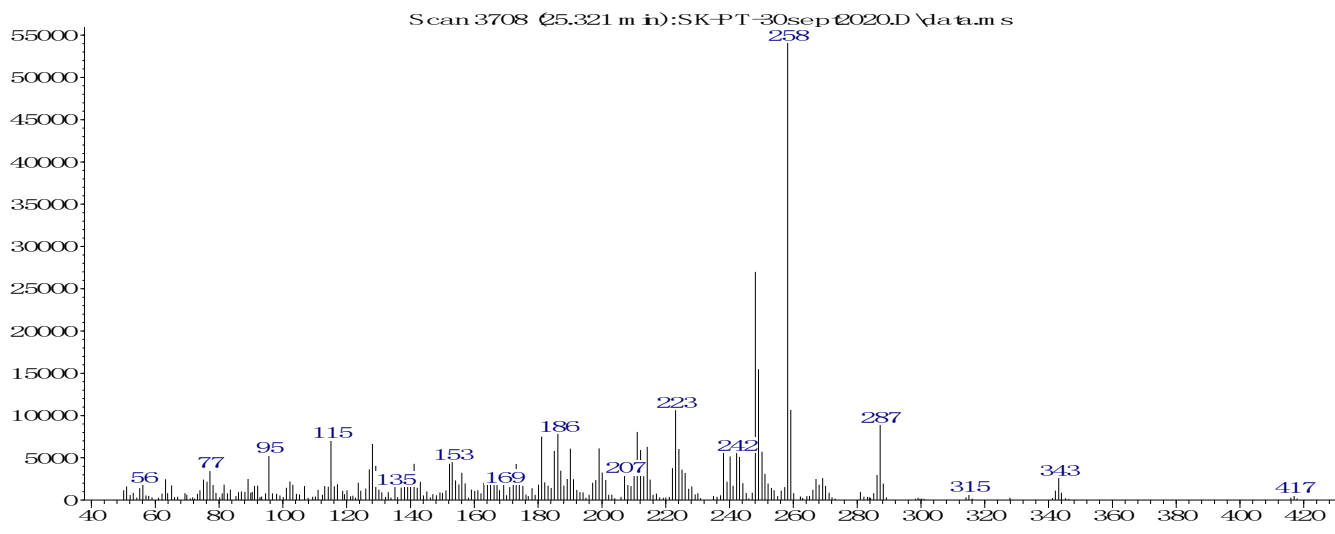

Triphaeridine (6)

Abundance

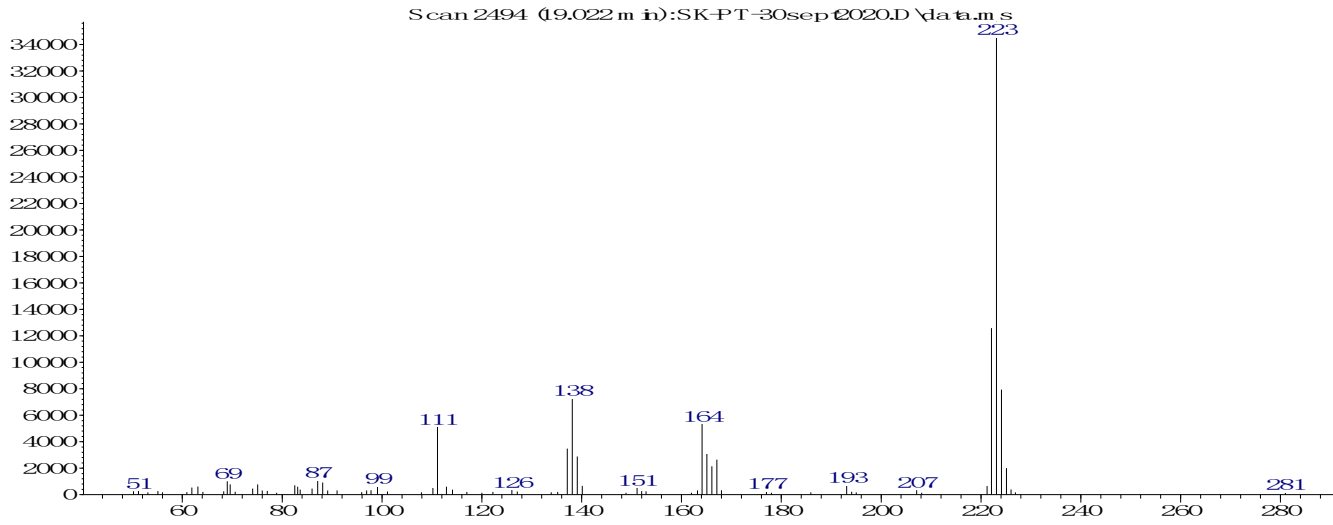

Figure A3. Cont. 
Unidentified (7)

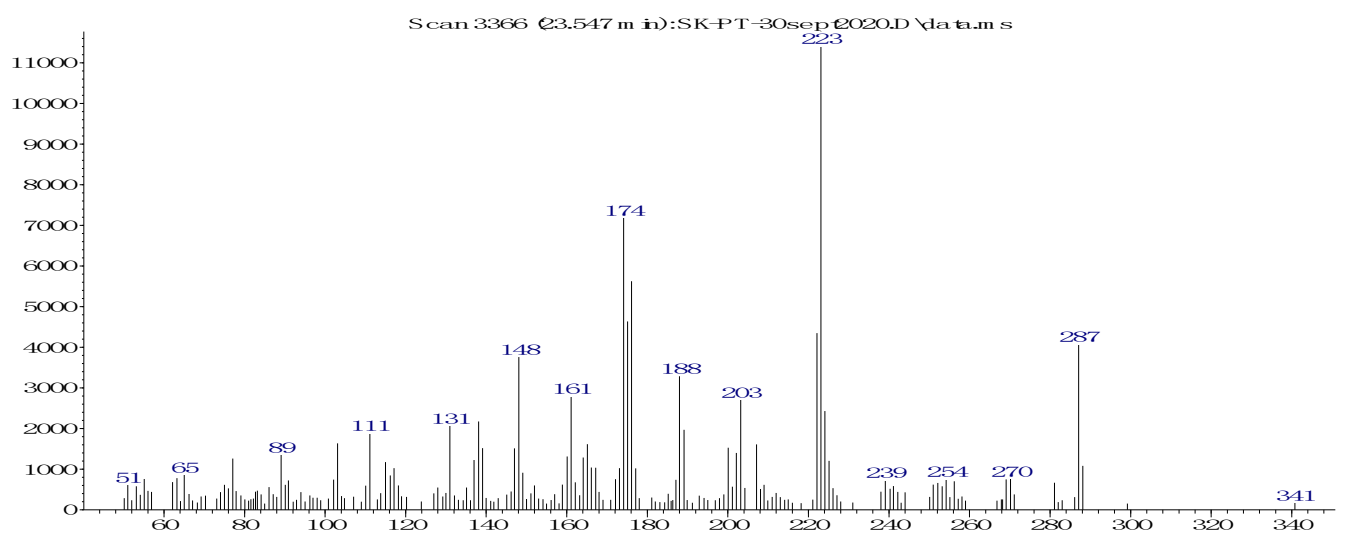

Unidentified (8)

Abundance

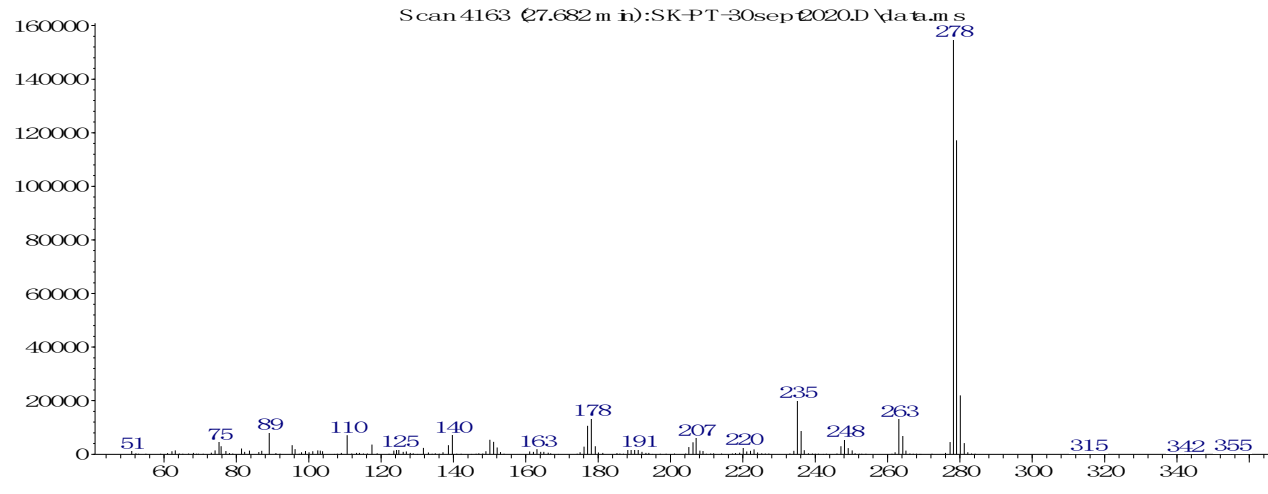

Figure A3. Mass spectra of alkaloids extracted from P. trianthum obtained by GC-MS analysis.

A

P. aeruginosa

ATCC 27253

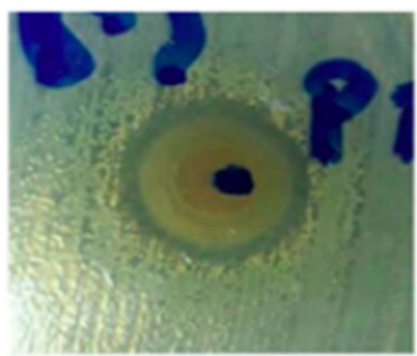

S. aureus

ATCC 29213

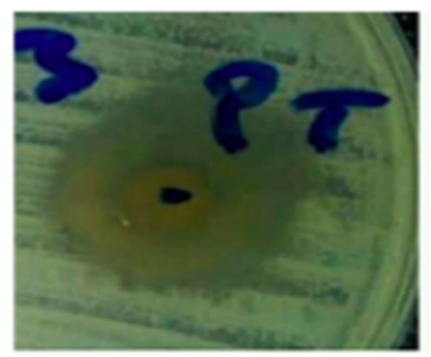

E. coli

ATCC 25922

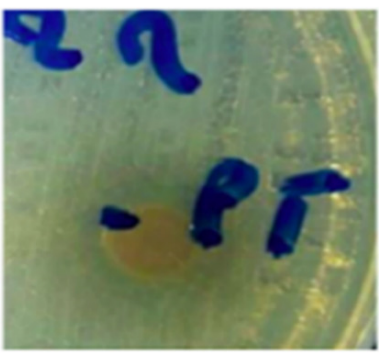

B

\begin{tabular}{|llll|}
\hline & P. aeruginosa & S. aureus & E. coli \\
\hline Growth inhibition area diameter $(\mathrm{mm})$ & 16 & 20 & 15 \\
MIC $(\mathrm{mg} / \mathrm{mL})$ & 2 & 1 & 2 \\
\hline
\end{tabular}

Figure A4. Antibacterial activity of $P$. trianthum alkaloid extracts. The effects of alkaloid extracts were measured on the growth of Pseudomonas aeruginosa, Staphylococcus aureus, and Escherichia coli. (A) Agar diffusion assay. Growth inhibition areas surrounding wells containing $16 \mathrm{mg} / \mathrm{mL}$ of extracts observed after $18-24 \mathrm{~h}$ incubation at $37^{\circ} \mathrm{C}$. (B) Quantification of the antibacterial activity as measured in the agar diffusion assay as well as using the minimum inhibitory concentration (MIC) approach (see Materials and Methods). 


\section{References}

1. Jin, Z.; Yao, G. Amaryllidaceae and Sceletium alkaloids. Nat. Prod. Rep. 2019, 36, 1462-1488. [CrossRef] [PubMed]

2. Nair, J.J.; Bastida, J.; Codina, C.; Viladomat, F.; van Staden, J. Alkaloids of the South African Amaryllidaceae: A review. Nat. Prod. Commun. 2013, 8, 1934578X1300800938. [CrossRef]

3. Meerow, A.; Snijman, D. Amaryllidaceae. In Flowering Plants.Monocotyledons; Springer: Berlin/Heidelberg, Germany, 1998; pp. 83-110.

4. Kerharo, J.; Bouquet, A. Plantes médicinales et toxiques de la Côte d'Ivoire-Haute-Volta: Mission d'étude de la pharmacopée indigène en AOF; Editions Vigot: Paris, France, 1950; 297p.

5. Kerharo, J.; Adam, J.-G. La pharmacopée sénégalaise traditionnelle: Plantes médicinales et toxiques; Editions Vigot frères: Paris, France, $1974 ; 1011 p$.

6. Kornienko, A.; Evidente, A. Chemistry, biology, and medicinal potential of narciclasine and its congeners. Chem. Rev. 2008, 108, 1982-2014. [CrossRef]

7. Cahlíková, L.; Benesová, N.; Macákova, K.; Urbanová, K.; Opletal, L. GC/MS analysis of three Amaryllidaceae species and their cholinesterase activity. Nat. Prod. Commun. 2011, 6, 1255-1258. [CrossRef]

8. Cheesman, L.; Nair, J.J.; van Staden, J. Antibacterial activity of crinane alkaloids from Boophone disticha (Amaryllidaceae). J. Ethnopharmacol. 2012, 140, 405-408. [CrossRef] [PubMed]

9. Havelek, R.; Seifrtova, M.; Kralovec, K.; Bruckova, L.; Cahlikova, L.; Dalecka, M.; Vavrova, J.; Rezacova, M.; Opletal, L.; Bilkova, Z. The effect of Amaryllidaceae alkaloids haemanthamine and haemanthidine on cell cycle progression and apoptosis in p53-negative human leukemic Jurkat cells. Phytomed. Int. J. Phytother. Phytopharm. 2014, 21, 479-490. [CrossRef] [PubMed]

10. Habartová, K.; Cahlíková, L.; Řezáčová, M.; Havelek, R. The Biological Activity of Alkaloids from the Amaryllidaceae: From Cholinesterases Inhibition to Anticancer Activity. Nat. Prod. Commun. 2016, 11, 1587-1594. [CrossRef]

11. Cahlíková, L.; Vaněčková, N.; Šafratová, M.; Breiterová, K.; Blunden, G.; Hulcová, D.; Opletal, L. The Genus Nerine Herb. (Amaryllidaceae): Ethnobotany, Phytochemistry, and Biological Activity. Molecules 2019, 24, 4238. [CrossRef] [PubMed]

12. Hulcova, D.; Marikova, J.; Korabecny, J.; Hostalkova, A.; Jun, D.; Kunes, J.; Chlebek, J.; Opletal, L.; De Simone, A.; Novakova, L.; et al. Amaryllidaceae alkaloids from Narcissus pseudonarcissus L. cv. Dutch Master as potential drugs in treatment of Alzheimer's disease. Phytochemistry 2019, 165, 112055. [CrossRef] [PubMed]

13. Al Shammari, L.; Al Mamun, A.; Koutová, D.; Majorošová, M.; Hulcová, D.; Šafratová, M.; Breiterová, K.; Maříková, J.; Havelek, R.; Cahlíková, L. Alkaloid profiling of Hippeastrum cultivars by GC-MS, isolation of Amaryllidaceae alkaloids and evaluation of their cytotoxicity. Rec. Nat. Prod. 2020, 14, 154-159. [CrossRef]

14. Cahlíková, L.; Breiterová, K.; Opletal, L. Chemistry and Biological Activity of Alkaloids from the Genus Lycoris (Amaryllidaceae). Molecules 2020, 25, 4797. [CrossRef]

15. Koutová, D.; Maafi, N.; Havelek, R.; Opletal, L.; Blunden, G.; Řezáčová, M.; Cahlíková, L. Chemical and Biological Aspects of Montanine-Type Alkaloids Isolated from Plants of the Amaryllidaceae Family. Molecules 2020, 25, 2337. [CrossRef]

16. Marikova, J.; Mamun, A.A.; Shammari, L.A.; Korabecny, J.; Kucera, T.; Hulcova, D.; Kunes, J.; Malanik, M.; Vaskova, M.; Kohelova, E.; et al. Structure Elucidation and Cholinesterase Inhibition Activity of Two New Minor Amaryllidaceae Alkaloids. Molecules 2021, 26, 1279. [CrossRef]

17. Ba, D. Le Pancratium trianthum. Available online: http://seyilaabe-htkm.blogspot.com/2015/10/ (accessed on 25 November 2020).

18. Ioset, J.-R.; Marston, A.; Gupta, M.P.; Hostettmann, K. A methylflavan with free radical scavenging properties from Pancratium littorale. Fitoterapia 2001, 72, 35-39. [CrossRef]

19. Sanaa, A.; Boulila, A.; Bejaoui, A.; Boussaid, M.; Fadhel, N.B. Variation of the chemical composition of floral volatiles in the endangered Tunisian Pancratium maritimum L. populations (Amaryllidaceae). Ind. Crops Prod. 2012, 40, 312-317. [CrossRef]

20. Berhaut, J. Flora of Senegal; Editions Clairafrique: Dakar, Senegal, 1967; 485p.

21. Schultes, E.R. Atlas des Plantes Hallucinogènes du Monde; Editions de l'Aurore: Montréal, QC, Canada, 1978; 112p.

22. Monteil, V. Contribution à l'étude de la flore du Sahara occidental II. Institut des Hautes Etudes Marocaines; Notes Documents VI; Éditions Larose: Paris, France, 1953; 120p.

23. Desgagne-Penix, I. Biosynthesis of alkaloids in Amaryllidaceae plants: A review. Phytochem. Rev. 2021, 20, 409-431. [CrossRef]

24. Ka, S.; Merindol, N.; Koirala, M.; Desgagne-Penix, I. Biosynthesis and biological activities of newly discovered Amaryllidaceae alkaloids. Molecules 2020, 25, 4901. [CrossRef]

25. Hotchandani, T.; Desgagne-Penix, I. Heterocyclic Amaryllidaceae Alkaloids: Biosynthesis and Pharmacological Applications. Curr. Top. Med. Chem. 2017, 17, 418-427. [CrossRef]

26. Heinrich, M. Galanthamine from Galanthus and other Amaryllidaceae-chemistry and biology based on traditional use. In The Alkaloids: Chemistry and Biology; Elsevier: Amsterdam, The Netherlands, 2010; Volume 68, pp. 157-165.

27. Naidoo, D.; Roy, A.; Slavětínská, L.P.; Chukwujekwu, J.C.; Gupta, S.; Van Staden, J. New role for crinamine as a potent, safe and selective inhibitor of human monoamine oxidase B: In vitro and in silico pharmacology and modeling. J. Ethnopharmacol. 2020, 248, 112305. [CrossRef]

28. Ka, S.; Merindol, N.; Sow, A.A.; Singh, A.; Landelouci, K.; Plourde, M.B.; Pépin, G.; Masi, M.; Di Lecce, R.; Evidente, A.; et al. Amaryllidaceae alkaloid cherylline inhibits the replication of dengue and Zika viruses. Antimicrob. Agents Chemother. 2021, 65, e0039821. [CrossRef] 
29. Ka, S.; Masi, M.; Merindol, N.; Di Lecce, R.; Plourde, M.B.; Seck, M.; Gorecki, M.; Pescitelli, G.; Desgagne-Penix, I.; Evidente, A. Gigantelline, gigantellinine and gigancrinine, cherylline- and crinine-type alkaloids isolated from Crinum jagus with antiacetylcholinesterase activity. Phytochemistry 2020, 175, 112390. [CrossRef]

30. Cedrón, J.C.; Del Arco-Aguilar, M.; Estévez-Braun, A.; Ravelo, Á.G. Chemistry and biology of Pancratium alkaloids. In The Alkaloids: Chemistry and Biology; Elsevier: Amsterdam, The Netherlands, 2010; Volume 68, pp. 1-37.

31. Frederik, D.M.; Murav'eva, D. Alkaloid composition of Pancratium trianthum. Chem. Nat. Compd. 1983, 18, 510. [CrossRef]

32. Chapter 1 Occurrence of Alkaloids in Plant Species. Chem. Nat. Compd. 1996, 32, 104-173. [CrossRef]

33. De Castro, O.; Brullo, S.; Colombo, P.; Jury, S.; De Luca, P.; Di Maio, A. Phylogenetic and biogeographical inferences for Pancratium (Amaryllidaceae), with an emphasis on the Mediterranean species based on plastid sequence data. Bot. J. Linn. Soc. 2012, 170, 12-28. [CrossRef]

34. Dereeper, A.; Guignon, V.; Blanc, G.; Audic, S.; Buffet, S.; Chevenet, F.; Dufayard, J.-F.; Guindon, S.; Lefort, V.; Lescot, M. Phylogeny. fr: Robust phylogenetic analysis for the non-specialist. Nucleic Acids Res. 2008, 36 (Suppl. 2), W465-W469. [CrossRef]

35. Tallini, L.R.; Andrade, J.P.; Kaiser, M.; Viladomat, F.; Nair, J.J.; Zuanazzi, J.A.S.; Bastida, J. Alkaloid Constituents of the Amaryllidaceae Plant Amaryllis belladonna L. Molecules 2017, 22, 1437. [CrossRef]

36. Trujillo-Chacón, L.M.; Pastene-Navarrete, E.R.; Bustamante, L.; Baeza, M.; Alarcón-Enos, J.E.; Cespedes-Acuña, C.L. In vitro micropropagation and alkaloids analysis by GC-MS of Chilean Amaryllidaceae plants: Rhodophiala pratensis. Phytochem. Anal. 2020, 31, 46-56. [CrossRef]

37. López, S.; Bastida, J.; Viladomat, F.; Codina, C. Acetylcholinesterase inhibitory activity of some Amaryllidaceae alkaloids and Narcissus extracts. Life Sci. 2002, 71, 2521-2529. [CrossRef]

38. Houghton, P.J.; Ren, Y.; Howes, M.-J. Acetylcholinesterase inhibitors from plants and fungi. Nat. Prod. Rep. 2006, 23, 181-199. [CrossRef]

39. Houghton, P.J.; Agbedahunsi, J.M.; Adegbulugbe, A. Choline esterase inhibitory properties of alkaloids from two Nigerian Crinum species. Phytochemistry 2004, 65, 2893-2896. [CrossRef]

40. Orhan, I.; Sener, B. Bioactivity-directed fractionation of alkaloids from some Amaryllidaceae plants and their anticholinesterase activity. Chem. Nat. Compd. 2003, 39, 383-386. [CrossRef]

41. Soltan, M.M.; Hamed, A.R.; Hetta, M.H.; Hussein, A.A. Egyptian Pancratium maritimum L. flowers as a source of anti-Alzheimer's agents. Bull. Fac. Pharm. Cairo Univ. 2015, 53, 19-22. [CrossRef]

42. Lamoral-Theys, D.; Andolfi, A.; Van Goietsenoven, G.; Cimmino, A.; Le Calvé, B.; Wauthoz, N.; Mégalizzi, V.; Gras, T.; Bruyère, C.; Dubois, J. Lycorine, the main phenanthridine Amaryllidaceae alkaloid, exhibits significant antitumor activity in cancer cells that display resistance to proapoptotic stimuli: An investigation of structure-activity relationship and mechanistic insight. J. Med. Chem. 2009, 52, 6244-6256. [CrossRef]

43. Lamoral-Theys, D.; Decaestecker, C.; Mathieu, V.; Dubois, J.; Kornienko, A.; Kiss, R.; Evidente, A.; Pottier, L. Lycorine and its derivatives for anticancer drug design. Mini-Rev. Med. Chem. 2010, 10, 41-50. [CrossRef]

44. Bonvicini, F.; Antognoni, F.; Iannello, C.; Maxia, A.; Poli, F.; Gentilomi, G.A. Relevant and selective activity of Pancratium illyricum L. against Candida albicans clinical isolates: A combined effect on yeast growth and virulence. BMC Complement. Altern. Med. 2014, 14, 409. [CrossRef]

45. Adesanya, S.; Olugbade, T.; Odebiyl, O.; Aladesanmi, J. Antibacterial alkaloids in Crinum jagus. Int. J. Pharmacogn. 1992, 30, 303-307. [CrossRef]

46. Tan, C.-X.; Schrader, K.K.; Mizuno, C.S.; Rimando, A.M. Activity of lycorine analogues against the fish bacterial pathogen Flavobacterium columnare. J. Agric. Food Chem. 2011, 59, 5977-5985. [CrossRef]

47. Evidente, A.; Andolfi, A.; Abou-Donia, A.H.; Touema, S.M.; Hammoda, H.M.; Shawky, E.; Motta, A. (-)-Amarbellisine, a lycorine-type alkaloid from Amaryllis belladonna L. growing in Egypt. Phytochemistry 2004, 65, 2113-2118. [CrossRef]

48. UNAIDS. Country Factsheets SENEGAL. 2020. Available online: https://www.unaids.org/sites/default/files/media_asset/20 20_aids-data-book_en.pdf (accessed on 3 November 2021).

49. Peng, X.; Sova, P.; Green, R.R.; Thomas, M.J.; Korth, M.J.; Proll, S.; Xu, J.; Cheng, Y.; Yi, K.; Chen, L. Deep sequencing of HIV-infected cells: Insights into nascent transcription and host-directed therapy. J. Virol. 2014, 88, 8768-8782. [CrossRef]

50. Szlavik, L.; Gyuris, A.; Minarovits, J.; Forgo, P.; Molnar, J.; Hohmann, J. Alkaloids from Leucojum vernum and antiretroviral activity of Amaryllidaceae alkaloids. Planta Med. 2004, 70, 871-873. [CrossRef] [PubMed]

51. Abd Kadir, S.L.; Yaakob, H.; Zulkifli, R.M. Potential anti-dengue medicinal plants: A review. J. Nat. Med. 2013, 67, 677-689. [CrossRef]

52. Wang, P.; Li, L.F.; Wang, Q.Y.; Shang, L.Q.; Shi, P.Y.; Yin, Z. Anti-dengue-virus activity and structure-activity relationship studies of lycorine derivatives. ChemMedChem 2014, 9, 1522-1533. [CrossRef]

53. Chen, H.; Lao, Z.; Xu, J.; Li, Z.; Long, H.; Li, D.; Lin, L.; Liu, X.; Yu, L.; Liu, W.; et al. Antiviral activity of lycorine against Zika virus in vivo and in vitro. Virology 2020, 546, 88-97. [CrossRef]

54. Zou, G.; Puig-Basagoiti, F.; Zhang, B.; Qing, M.; Chen, L.; Pankiewicz, K.W.; Felczak, K.; Yuan, Z.; Shi, P.-Y. A single-amino acid substitution in West Nile virus 2K peptide between NS4A and NS4B confers resistance to lycorine, a flavivirus inhibitor. Virology 2009, 384, 242-252. [CrossRef] [PubMed]

55. de Andrade, J.P.; Guo, Y.; Font-Bardia, M.; Calvet, T.; Dutilh, J.; Viladomat, F.; Codina, C.; Nair, J.J.; Zuanazzi, J.A.S.; Bastida, J. Crinine-type alkaloids from Hippeastrum aulicum and H. calyptratum. Phytochemistry 2014, 103, 188-195. [CrossRef] 
56. Sasidharan, S.; Chen, Y.; Saravanan, D.; Sundram, K.M.; Yoga Latha, L. Extraction, isolation and characterization of bioactive compounds from plants' extracts. Afr. J. Tradit. Complement. Altern. Med. 2011, 8, 1-10. [CrossRef]

57. Robles, M.A. Modified Dragendorff reagent for the procurement of lasting coloration of spots in paper chromatographic and electrophoretic investigation of alkaloids. Pharm. Weekbl. 1959, 94, 178-179.

58. Singh, A.; Desgagné-Penix, I. Transcriptome and metabolome profiling of Narcissus pseudonarcissus 'King Alfred' reveal components of Amaryllidaceae alkaloid metabolism. Sci. Rep. 2017, 7, 17356. [CrossRef] [PubMed]

59. Tallini, L.R.; Torras-Claveria, L.; Borges, W.S.; Kaiser, M.; Viladomat, F.; Zuanazzi, J.A.S.; Bastida, J. N-oxide alkaloids from Crinum amabile (Amaryllidaceae). Molecules 2018, 23, 1277. [CrossRef] [PubMed]

60. Uzé, G.; Di Marco, S.; Mouchel-Vielh, E.; Monneron, D.; Bandu, M.-T.; Horisberger, M.A.; Dorques, A.; Lutfalla, G.; Mogensen, K.E. Domains of interaction between alpha interferon and its receptor components. J. Mol. Biol. 1994, 243, 245-257. [CrossRef]

61. Fischl, W.; Bartenschlager, R. High-throughput screening using dengue virus reporter genomes. In Antiviral Methods and Protocols; Springer: Berlin/Heidelberg, Germany, 2013; pp. 205-219.

62. He, J.; Chen, Y.; Farzan, M.; Choe, H.; Ohagen, A.; Gartner, S.; Busciglio, J.; Yang, X.; Hofmann, W.; Newman, W.; et al. CCR3 and CCR5 are co-receptors for HIV-1 infection of microglia. Nature 1997, 385, 645-649. [CrossRef]

63. Shawky, E. Phytochemical and Biological Investigation of Clivia nobilis Flowers Cultivated in Egypt. Iran. J. Pharm. Res. IJPR 2016, 15, 531-535.

64. Balouiri, M.; Sadiki, M.; Ibnsouda, S.K. Methods for in vitro evaluating antimicrobial activity: A review. J. Pharm. Anal. 2016, 6, 71-79. [CrossRef] 